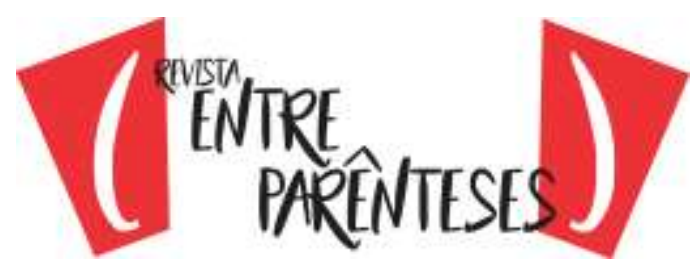

ISSN 2238-4502

\section{A PRODUTIVIDADE DE RUÍNAS DA DISSERTAÇÃO DE VESTIBULAR/REDAÇÃO DO ENEM EM RESENHAS NA UNIVERSIDADE}

\author{
Maria Luiza Alves \\ PG-Universidade Estadual de Campinas \\ (marialuiza.11@hotmail.com)
}

\begin{abstract}
Resumo
Este trabalho objetiva analisar ruínas (CORRÊA, 2006) do gênero redação escolar presentes no gênero resenha. Especificamente, pretende-se, buscando refletir sobre como tem sido desenvolvido o ensino de escrita nesses níveis de escolarização: (a) analisar de que forma o escrevente se vale da estrutura composicional de outros gêneros na elaboração de uma resenha; (b) investigar em que medida o escrevente dialoga com práticas de letramentos escolares típicas da educação básica e de que forma se utiliza dessas práticas na elaboração do gênero resenha; (c) analisar como o escrevente se insere (ou tenta se inserir) em práticas de escrita da esfera acadêmica e (d) refletir sobre o ensino de escrita na educação básica e na universidade a partir dos indícios da imagem que o escrevente faz da escrita nesses níveis de escolarização. 0 corpus são resenhas produzidas por discentes de Letras em dois eventos: um curso de extensão e uma disciplina obrigatória do Curso de Letras de uma universidade pública. Para a análise, optou-se pelo paradigma indiciário (GINZBURG, 1991) a fim de identificar pistas linguísticas para a análise dos gestos do escrevente na produção do gênero resenha. Verificou-se, assim, por meio das escolhas lexicais e também da estrutura das resenhas produzidas, um trânsito na escrita do escrevente entre a redação de vestibular e a resenha, uma vez que ora se apresentou um diálogo com as práticas de letramentos escolares típicas da educação básica, ora com as práticas de escrita do contexto universitário. Tal aspecto reforça a ideia de que o trabalho com a escrita, de um modo geral, deveria se distanciar da noção de linguagem como adequação ao modelo para dar lugar à concepção de escrita como processo e à linguagem como acontecimento. Conclui-se que as ruínas de um gênero em outro podem se configurar um recurso positivo para a construção da prática de escrita do gênero resenha e, consequentemente, das práticas de letramentos desse escrevente.
\end{abstract}

Palavras-chave: Letramento. Escrita acadêmica. Redação escolar.

DOI: https://doi.org/10.32988/rep.v10n1.1561

Dossiê "Possibilidades de trabalho com a Língua Portuguesa"

\begin{tabular}{|l|l|l|l|l|l|l|} 
Revista (Entre Parênteses) & Alfenas, MG & v. 10 & n. 1 & $1-33$ & e021013 & 2021 \\
\hline
\end{tabular}




\section{Maria Luiza Alves}

Possui graduação em Letras - Licenciatura em Língua Portuguesa e em Língua Espanhola, pela Universidade Federal de Alfenas (Unifal-MG), e mestrado em Linguística Aplicada, pela Universidade Estadual de Campinas (Unicamp), na linha de pesquisa "Linguagens e Educação". Atuou como bolsista do Grupo PET/Conexões de Saberes - Letras, como voluntária do Programa de Extensão sou+tec e como preceptora do Programa de Residência Pedagógica, da Universidade Federal de Alfenas (Unifal-MG). Atualmente, é professora de Língua Portuguesa e de Redação na Educação Básica.

\section{$\underline{\text { http://lattes.cnpq.br/3253737905546876 }}$}

https://orcid.org/0000-0002-1295-4763

Grupo de Pesquisa Práticas de escrita e de reflexão sobre a escrita em contextos institucionais - Unicamp

DOI: https://doi.org/10.32988/rep.v10n1.1561

Dossiê "Possibilidades de trabalho com a Língua Portuguesa"

v. 10

n. 1

$1-33$

e021013




\title{
(")
}

ISSN 2238-4502

\section{A PRODUTIVIDADE DE RUÍNAS DA DISSERTAÇÃO DE VESTIBULAR/REDAÇÃO DO ENEM EM RESENHAS NA UNIVERSIDADE}

\author{
Maria Luiza Alves ${ }^{1}$ \\ PG-Unicamp \\ (marialuiza.11@hotmail.com)
}

Considerações iniciais

Em uma sociedade como a nossa, altamente dependente da leitura e da escrita, variados são os usos que fazemos dessas duas práticas, o que denominamos como letramentos (STREET, 2007). Dessa forma, em cada esfera em que nos situamos, determinadas práticas de escrita e de leitura nos são exigidas. Tal exigência se processa a todo indivíduo, independente se escolarizado ou não, o que nos leva a afirmar que até mesmo um sujeito que não teve aprendizagem formal das práticas de ler e de escrever pode ser considerado como um indivíduo letrado (TFOUNI, 2001).

Assim, ao tomar contato com diferentes práticas de leitura e de escrita, vamos formando uma espécie de repertório, a que, se for necessário, podemos recorrer quando nos deparamos com uma situação nova que exija a leitura e a escrita (DA SILVA, 2012). Quando o aluno ingressa na universidade, em muitos casos, não apresenta familiaridade com as práticas de escrita ${ }^{2}$ dessa esfera discursiva. No entanto, pode fazer uso, durante a produção de determinado gênero discursivo, de outras práticas com as quais teve contato, por exemplo, durante a educação básica, como uma tentativa de se inserir nesse contexto novo.

Ao ter contato com a escrita desses sujeitos por meio de resenhas produzidas em dois eventos discursivos distintos do contexto universitário, sendo esse nosso objeto de análise,

\footnotetext{
${ }^{1}$ Mestra em Linguística Aplicada (Unicamp), professora da Educação Básica na E.E. Pe. J. Grimminck (Alfenas/MG) e membro do Grupo de Pesquisa Práticas de escrita e de reflexão sobre a escrita em contextos institucionais (Unicamp).

2 Deste ponto em diante, atemo-nos ao termo "práticas de escrita" devido ao corpus selecionado para análise, Entendemos, contudo, que práticas de letramentos envolvem práticas de leitura e de escrita em diferentes contextos e situações comunicativas, incluindo as práticas orais das quais se valem os sujeitos cotidianamente.
}

DOI: https://doi.org/10.32988/rep.v10n1.1561

Dossiê "Possibilidades de trabalho com a Língua Portuguesa"

\begin{tabular}{|l|l|l|l|l|l|l|}
\hline Revista (Entre Parênteses) & Alfenas, MG & v. 10 & n. 1 & $1-33$ & e021013 & 2021 \\
\hline
\end{tabular}




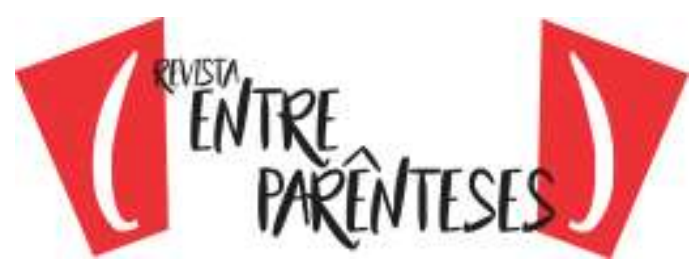

ISSN 2238-4502

podemos perceber ruínas, ${ }^{3}$ isto é, marcas de outros gêneros discursivos. Um exemplo dessas ruínas no gênero resenha, na esfera universitária, seria a redação escolar, ${ }^{4}$ gênero trabalhado no ensino médio e cursos pré-vestibulares.

Os objetivos deste trabalho são: analisar as ruínas do gênero redação escolar presentes no gênero resenha; analisar de que forma o escrevente ${ }^{5}$ se vale da estrutura composicional de outros gêneros na elaboração de uma resenha; investigar em que medida o escrevente dialoga com práticas de letramentos escolares típicas da educação básica e de que forma se utiliza dessas práticas na elaboração do gênero resenha; analisar como o escrevente se insere (ou tenta se inserir) em práticas de escrita da esfera acadêmica e refletir sobre o ensino de escrita na educação básica e na universidade a partir dos indícios da imagem que o escrevente faz da escrita nesses níveis de ensino.

Para tanto, serão utilizadas resenhas de alunos dos períodos iniciais de um Curso de Letras de uma universidade pública, produzidas, em um primeiro momento, como atividade final de um Curso de Extensão Universitária: "Escrita acadêmica: o gênero Resenha", na modalidade a distância, oferecido em 2013, e da disciplina de Linguística III, obrigatória no Curso de Letras da referida universidade, oferecida em 2014.

Para a análise dos dados, será utilizado o paradigma indiciário (GINZBURG, 1991) já que este modelo propõe, como importantes, indícios, dados que geralmente são desconsiderados, mas que podem oferecer informações relevantes em relação ao processo de produção do gênero discursivo resenha, bem como do ensino desse e de outros gêneros, como a redação escolar, por exemplo. Assim, ao considerar que um gênero discursivo pode apresentar ruínas de outros, os conceitos que regem este trabalho são o de dialogismo, proposto por Bakhtin (1991), e o das relações intergenéricas, proposto por Corrêa (2006) que se apoia em Bakhtin. Tais conceitos nos fazem considerar que tudo o que é produzido em termos de linguagem se realiza tendo como preocupação o outro, isto é, aquele que, mesmo fisicamente ausente, é o interlocutor do nosso dizer.

\section{Aspectos teórico-metodológicos}

Na escola e fora dela, entende-se ser necessário que os indivíduos tenham contato com diferentes práticas de escrita. Tfouni (2001, p. 78) afirma que, na sociedade grafocêntrica, "a escrita passa a funcionar como mediadora entre estas [práticas sociais] e o sujeito". A esses

\footnotetext{
${ }^{3}$ Este conceito será explicitado mais adiante.

${ }^{4}$ Entendemos, neste trabalho, "redação escolar" como os textos cuja finalidade é treinar o aluno para a produção de dissertações no vestibular ou, ainda, resguardadas as suas particularidades, na prova de Redação do Enem, em que é exigida a produção de um texto do tipo dissertativo-argumentativo.

5 Usaremos, neste trabalho, indistintamente, "escrevente”, “aluno”, “estudante”, "graduando" e "universitário”, mas referindo-nos sempre aos sujeitos de pesquisa que cederam o material para a análise.
}

DOI: https://doi.org/10.32988/rep.v10n1.1561

Dossiê "Possibilidades de trabalho com a Língua Portuguesa"

\begin{tabular}{|l|l|l|l|l|l|l|}
\hline Revista (Entre Parênteses) & Alfenas, MG & v. 10 & n. 1 & $1-33$ & e021013 & 2021 \\
\hline
\end{tabular}




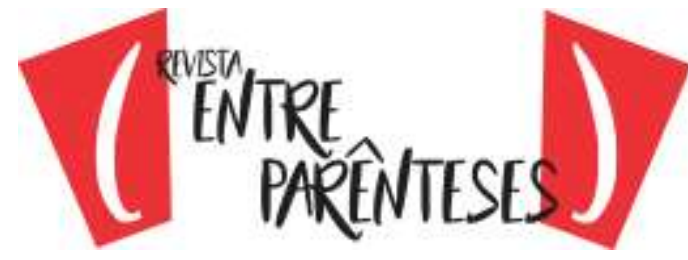

ISSN 2238-4502

diversos usos da escrita, denominamos letramentos (STREET, 2007). Já que diversos são os usos da escrita, não admitimos a existência de um modelo autônomo de letramentos, concordando com Street (2007), mas sim de um modelo ideológico, que nos direciona para a multiplicidade de práticas de uso da escrita.

A linguagem, para Voloshinov (p. 1), não é algo pronto, acabado, "é um produto da vida social, a qual não é fixa e nem petrificada: [...] encontra-se em um perpétuo devir e seu desenvolvimento segue a evolução da vida social". Considerando que a constituição da linguagem, "segue a evolução da vida social", não há como deixar de levar em conta que todo uso que fazemos dela é destinado a alguém, ou seja, "toda expressão linguística é sempre orientada em direção ao outro, em direção ao ouvinte, mesmo quando este outro se encontra fisicamente ausente". Assim, podemos perceber o caráter dialógico da linguagem de que trata Voloshinov, no sentido de "que toda comunicação, toda interação verbal, se realiza sob a forma de uma troca de enunciados, isto é, na dimensão de um diálogo" (p. 4). Em outras palavras, dizer que a linguagem possui um caráter dialógico significa que, sempre quando vamos conceber qualquer enunciado, levamos em conta aquele que será nosso interlocutor (VOLOSHINOV, s.d.). A partir daí o interlocutor vai, por exemplo, concordar, refutar e expandir o que foi enunciado, assumindo, assim, "uma atitude responsiva ativa" (BAKHTIN, 1997, p. 290) em relação àquilo que foi dito, produzindo enunciados que são denominados "réplicas" (Ibid., 1997, p. 294). É por meio da réplica, que carrega em si a "posição do locutor", que é possível assumir, segundo Bakhtin (Ibid., p. 294), "uma posição responsiva".

Concordando com Corrêa (2006, p. 207), consideramos ainda que os gêneros discursivos se constituem e se redefinem "em função de relações intergenéricas", ou seja, de relações com outros gêneros discursivos, podendo haver, assim, nas mais diversas práticas sociais de uso da escrita, um imbricamento entre os textos que são produzidos. Isto é, em determinado contexto, as práticas de escrita produzidas/utilizadas podem sofrer influências de outras práticas a que os sujeitos foram submetidos em outros campos da vida social. Esse fato pode ocorrer devido à continuidade do processo de letramentos na vida dos sujeitos, pois se considera que, ao contrário da alfabetização, "o letramento é um processo constante e infinito" (DA SILVA, 2012, p. 138) que vai sendo 'atualizado' conforme surgem novas situações comunicativas que, por sua vez, exigem diferentes práticas letradas. ${ }^{6}$ Assim, já que o letramento é um processo sem um prazo para o seu término, no decorrer da vida, o sujeito vai constituindo

\footnotetext{
${ }^{6}$ Consideramos, assim como Tfouni (2001), que, mesmo sem ter um contato com a escolarização, o indivíduo, em nossa sociedade, não pode ser considerado um sujeito iletrado. Tal fato ocorre porque, ainda que as pessoas não sejam alfabetizadas, "[...] existe um conhecimento sobre a escrita que [...] dominam mesmo sem saber ler e escrever, que é adquirido desde que estas estejam inseridas em uma sociedade letrada” (TFOUNI, 2001, p. 78). A autora argumenta que é inevitável, numa sociedade letrada como a nossa, a pessoa não estar exposta a práticas de leitura e de escrita. Assim, um aluno, na educação básica, pode não possuir as habilidades de ler e de escrever quando ingressa na escola, no entanto, isso não quer dizer que ele não possa se configurar um sujeito letrado em outras práticas com as quais teve contato. No contexto desta pesquisa, o trabalho se volta para sujeitos em processo de escolarização, mas que dialogam com outras práticas de letramentos, além daquelas com que têm contato no contexto escolar.
}

DOI: https://doi.org/10.32988/rep.v10n1.1561

Dossiê "Possibilidades de trabalho com a Língua Portuguesa"

\begin{tabular}{|l|l|l|l|l|l|l|} 
Revista (Entre Parênteses) & Alfenas, MG & v. 10 & n. 1 & $1-33$ & e021013 & 2021 \\
\hline
\end{tabular}




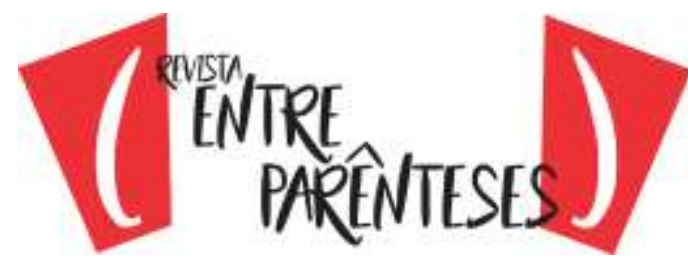

ISSN 2238-4502

seu Histórico de Letramento, ou seja, vai se familiarizando com diferentes práticas tanto de leitura quanto de escrita (DA SILVA, 2012).

Como o sujeito vai vivenciando diferentes práticas letradas, entendemos que, no contato com novas práticas, num processo contínuo de atualização e de inovação, ele pode fazer uso das que já conhece para se adaptar aos 'requisitos' exigidos pela nova situação comunicativa. Com isso, assumimos a existência de ruínas, ou seja, "partes mais ou menos informes de gêneros discursivos" que podem se fazer presentes em outros gêneros, obtendo, assim, "o estatuto de fontes históricas - retrospectivas ou prospectivas - da constituição de uma fala ou de uma escrita" (CORRÊA, 2006, p. 209).

No entanto, ao assumir a utilização do termo ruínas, assim como Corrêa (2006), não estamos indicando que a influência que um texto pode sofrer de outros textos seja algo negativo e que necessite ser apagada/corrigida do/no texto do aluno. Concebemos as ruínas de um gênero em outro como algo positivo e que parece nos indicar a tentativa de o escrevente produzir o texto que lhe foi solicitado. Em alguns casos, o professor não deixa claro de que forma o texto se constitui e não aponta que as relações intergenéricas também são constitutivas de um gênero. Com isso, a produção de um gênero com o qual o aluno não teve (ou teve pouco) contato configura-se um desafio ainda maior.

Dessa forma, na tentativa de superar o desafio imposto, o aluno se vale das experiências sociais construídas ao longo de sua vida e das relações que estabelece com diferentes gêneros do discurso para construir aquilo que ainda é novo e que, em muitos casos, causa certa estranheza e insegurança. Assim, a existência dessas ruínas pode indicar ao professor que esse aluno ainda não domina a produção do gênero proposto, mas que, por considerar que há aspectos em comum com os textos que já produziu, utiliza-se deles para a construção de um novo texto. Além disso, indica-nos a tentativa de inserção em práticas de leitura e de escrita até então desconhecidas pelos alunos, mostrando que há um esforço para 'fazer parte' da esfera discursiva em que tal texto é produzido.

Retomando um dos objetivos desta pesquisa investigar práticas de letramentos específicas do contexto universitário „, percebemos que ingressantes em um curso superior têm dificuldades em produzir textos da esfera universitária, visto que aquelas práticas vivenciadas na educação básica se constituem de forma diversa das do ensino superior (FIAD, 2011; SILVA, 2012). Bakhtin (1997) mostra que em diferentes situações da vida cotidiana, os sujeitos podem se sentir despreparados em práticas de uso da língua até então desconhecidas, pois, "[s]ão muitas as pessoas que, dominando magnificamente a língua, sentem-se logo desamparadas em certas esferas da comunicação verbal, precisamente pelo fato de não dominarem, na prática, as formas do gênero de uma dada esfera" (Ibid., p. 303). No que concerne ao contexto universitário, Fiad (2011) comenta que, diante dessa realidade, muitos professores consideram tais "sujeitos como iletrados na universidade" (FIAD, 2011, p. 362), por não compreenderem que seus alunos somente ainda não se familiarizaram com as práticas específicas do discurso acadêmico e do contexto universitário.

Assim, já que se considera que um gênero discursivo pode apresentar ruínas de

DOI: https://doi.org/10.32988/rep.v10n1.1561

Dossiê "Possibilidades de trabalho com a Língua Portuguesa"

\begin{tabular}{|l|l|l|l|l|l|l} 
Revista (Entre Parênteses) & Alfenas, MG & v. 10 & n. 1 & $1-33$ & e021013 & 2021 \\
\hline
\end{tabular}




\section{("Eintrere}

ISSN 2238-4502

outros gêneros, as perguntas de pesquisa que orientam este trabalho são: (1) quais marcas linguístico-discursivas um ingressante no contexto universitário pode apresentar na produção de um gênero discursivo desse âmbito? e (2) se esse estudante estava inserido em práticas próprias da educação básica, será que elas podem orientar a escrita no novo contexto?

A resposta a essas questões pode contribuir para se problematizar o ensino de escrita na educação básica, tais como: (1) como ocorre a produção de textos na escola? (2) quais são os textos privilegiados? (3) qual a finalidade da produção desses textos? Ainda que essa problematização não seja o objeto de análise principal deste trabalho, entendemos que elas podem orientar a análise no sentido de que trabalhamos com a hipótese de que o universitário se utiliza do gênero conhecido (a redação escolar) quando é instado a produzir um (novo) gênero do discurso na academia. Em nosso caso, a resenha.

É recorrente, nas aulas de Língua Portuguesa, solicitar aos alunos a produção de tipos textuais ${ }^{7}$ (dissertativo, argumentativo, descritivo, entre outros) no lugar de gêneros textuais, conforme argumentam Azevedo (2006) e Silva (2012). Muitas vezes, o propósito dessa produção é um estudo formal da língua e não propriamente o aprender a escrever (SILVA, 2012). Dentre esses tipos textuais exigidos, vemos que é garantido muito espaço, principalmente no Ensino Médio, à famosa dissertação ou à redação escolar que é considerado "um gênero específico, de existência restrita ao âmbito da escola, sendo, portanto, desvinculado das práticas sociais de linguagem" (REINALDO, 2002, p. 97 apud AZEVEDO, 2006, p. 210). Considerando um possível imbricamento entre as práticas de escrita, entendemos que estudantes dos períodos iniciais no ensino superior, dado o contato que tiveram, na educação básica, com o gênero redação escolar (a dissertação para o vestibular ou a redação do Enem), podem apresentar ruínas desse gênero na produção de textos da esfera universitária, neste caso, do gênero resenha. A hipótese que norteia esta pesquisa é a de que os universitários se valem do gênero conhecido (a redação escolar) para produzirem o gênero resenha, solicitado na universidade, pois: (a) a redação escolar é o gênero trabalhado no ensino médio objetivando preparar o aluno para o ingresso em um curso superior e (b) como ingressaram no ensino superior, veem que obtiveram sucesso na empreitada, visto que um dos requisitos para passar no vestibular/no SISU/Enem é a obtenção de uma boa nota na redação.

Para tanto, serão utilizadas, como corpus, as produções escritas de 22 (vinte e dois) sujeitos de pesquisa, estudantes dos períodos iniciais do curso de Letras de uma universidade pública. 0 corpus foi coletado em dois eventos distintos. 0 primeiro refere-se ao curso, na

\footnotetext{
7 Segundo Marcuschi (2010, p. 23), o tipo textual constitui-se como "uma espécie de sequência teoricamente definida pela natureza linguística de sua composição [...]", ao passo que o gênero textual diz respeito a "uma noção propositalmente vaga para referir os textos materializados que encontramos em nossa vida diária e que apresentam características sociocomunicativas definidas por conteúdos, propriedades funcionais, estilo e composição característica" (MARCUSCHI, 2010, p. 23). (Grifos no original) Além disso, para marcar bem essa diferenciação, o autor cita que os tipos textuais são apenas o narrativo, o argumentativo, o expositivo, o descritivo e o injuntivo; os gêneros textuais, ao contrário, são inúmeros. Para citar alguns exemplos, temos, como gêneros textuais, a carta pessoal, a conferência, a resenha, a receita culinária, dentre outros.
}

DOI: https://doi.org/10.32988/rep.v10n1.1561

Dossiê "Possibilidades de trabalho com a Língua Portuguesa"

\begin{tabular}{|l|l|l|l|l|l|l} 
Revista (Entre Parênteses) & Alfenas, MG & v. 10 & n. 1 & $1-33$ & e021013 & 2021 \\
\hline
\end{tabular}




\section{("NinRE}

ISSN 2238-4502

modalidade a distância no Moodle, em 2013, com foco na produção do gênero acadêmico resenha. Os seis participantes e sujeitos de pesquisa contavam com idade entre 19 e 21 anos. Devido aos objetivos e hipótese desta pesquisa, foi excluído o aluno que já tinha cursado uma graduação.

No primeiro evento, coletamos resenhas produzidas pelos participantes do curso sobre um capítulo de um livro ou um artigo na área de Letras. A proposta feita aos cursistas era que encontrassem um artigo ou um livro na área de Letras para que, a partir da leitura dessa produção, resenhassem o texto lido a fim de que a resenha produzida pudesse ser uma espécie de filtro para a leitura de outras pessoas, isto é, tendo contato com a resenha, o leitor decidiria se o artigo ou mesmo o livro poderia ser interessante para ele.

Esperava-se que os graduandos demonstrassem conhecimento desse gênero discursivo, escrevendo um texto que apresentasse, de forma sucinta, a temática do que foi lido, apoiando-se em teorias da área, além de trazer, para o seu texto, as novidades da obra, seus pontos positivos e negativos, em suma, uma leitura crítica da obra. Dessa forma, outras vozes poderiam ser trazidas ao texto de forma a demonstrar um diálogo com a área de estudo a que a obra se filiava e também um assunto que, considerado de extrema importância, se constituísse como o fio condutor da resenha produzida. No entanto, chamou-nos a atenção o fato de que, no texto produzido pelos cursistas, apareceram marcas do gênero redação escolar, a famosa dissertação, praticada frequentemente na educação básica. Tal aspecto nos levou a considerar que, ainda que os alunos tenham se esforçado por escrever a resenha, texto muito comum no ambiente universitário, na tentativa de se inserirem nas práticas de escrita desse contexto, as práticas de letramentos que já eram comuns a eles, com especial atenção às do Ensino Médio, interferiram/se fizeram presentes na escrita desses sujeitos.

O segundo evento foi na disciplina obrigatória de Linguística III, do curso de Letras da mesma universidade, em 2014. Nessa disciplina, foi solicitada a produção de resenhas de artigos ou capítulos de livros da área de Letras. Os sujeitos de pesquisa, neste segundo evento, possuíam idade média entre 17 e 33 anos, eram alunos do terceiro período, tendo ingressando em Letras em 2013. Na análise, os sujeitos de pesquisa foram numerados e nos casos em que o sujeito possuía mais de uma resenha, esta foi nomeada com uma letra do alfabeto. Dessa foram, $5 \mathrm{~A}, 5 \mathrm{~B}, 5 \mathrm{C}$ em diante se referem ao número que identifica um determinado sujeito de pesquisa e " $A$ " ou " $B$ " ou "C" designam as diferentes produções escritas desse sujeito e assim sucessivamente.

Para a análise dos dados, foi utilizado o paradigma indiciário. Ginzburg (1991) aponta esse paradigma como um modelo de análise em que se ressaltam os pequenos detalhes, aquilo que não representa muita importância, por exemplo, dentro das características de uma escola artística a qual determinado pintor filia-se, mas que pode se constituir um elemento importante para se determinar a autoria de uma pintura. No paradigma indiciário, o importante é a consideração de indícios que estão à margem, isto é, fatos, informações, dados os quais, para a maioria das pessoas, são informações insignificantes.

Apresentamos, na sequência, os critérios utilizados para a análise das pistas

DOI: https://doi.org/10.32988/rep.v10n1.1561

Dossiê "Possibilidades de trabalho com a Língua Portuguesa"

\begin{tabular}{|l|l|l|l|l|l|l} 
Revista (Entre Parênteses) & Alfenas, MG & v. 10 & n. 1 & $1-33$ & e021013 & 2021 \\
\hline
\end{tabular}


linguísticas que possibilitaram alcançar os objetivos propostos nesta investigação:

\begin{tabular}{|l|}
\hline \multicolumn{1}{|c|}{ Escolhas lexicais usadas pelo sujeito de pesquisa para: } \\
\hline - designar pessoas; \\
- indicar hierarquia; \\
- demonstrar que se insere no discurso ou no espaço social da universidade; \\
\hline - indicar a avaliação por parte do aluno em relação ao texto lido; \\
\hline - nomear gêneros; \\
\hline - moldar a estrutura e estilo do gênero discursivo; \\
\hline - evidenciar familiaridade com as "regras" da escrita na universidade e com teóricos/pesquisadores. \\
\hline \\
\hline Estrutura dos gêneros redação escolar e resenha utilizada pelo sujeito de pesquisa para: \\
\hline - evidenciar o modelo proposto para uma dissertação; \\
- demonstrar a presença de uma tese a ser defendida; \\
- comprovar a retomada da tese defendida; \\
- indicar uma proposta de intervenção social; \\
- relacionar um gênero discursivo com outros.
\end{tabular}

Anteriormente à análise das resenhas, fizemos uma pesquisa documental sobre materiais didáticos para o ensino de texto (dissertação no contexto de vestibular) disponíveis na internet a fim de que pudéssemos observar orientações didáticas vivenciadas por alunos de Ensino Médio. Dos materiais pesquisados, foram selecionados dois materiais. A seleção se deu porque esses materiais apresentavam orientações que dialogavam com indícios encontrados nas resenhas e porque nos propusemos a refletir também, ainda que indiretamente, sobre práticas de ensino de escrita na educação básica.

\section{Os gêneros discursivos e as relações intergenéricas}

Bakhtin define o enunciado como "a unidade real da comunicação verbal" que é delimitada por fronteiras, além de sempre possuir "características estruturais que lhes são comuns" (1997, p. 293). As fronteiras que delimitam o enunciado "são determinadas pela alternância dos sujeitos falantes, ou seja, pela alternância dos locutores". Assim, o enunciado sempre estará delimitado pela alternância desses sujeitos, trazendo à tona o fato de que "o

DOI: https://doi.org/10.32988/rep.v10n1.1561

Dossiê "Possibilidades de trabalho com a Língua Portuguesa"

\begin{tabular}{|l|l|l|l|l|l|l} 
Revista (Entre Parênteses) & Alfenas, MG & v. 10 & n. 1 & $1-33$ & e021013 & 2021 \\
\hline
\end{tabular}




\title{
(")
}

ISSN 2238-4502

enunciado não é uma unidade convencional, mas uma unidade real" (Ibid., 1997, p. 294). Segundo o autor, aquilo que é dito (ou que será dito) sempre leva em conta a escolha de um gênero discursivo que é determinada, por sua vez, pelas necessidades da comunicação, pelos interlocutores, pelo assunto, dentre outros aspectos. Nas palavras de Bakhtin (Ibid., p. 301),

Essa escolha é determinada em função da especificidade de uma dada esfera da comunicação verbal, das necessidades de uma temática (do objeto do sentido), do conjunto constituído dos parceiros, etc. Depois disso, o intuito discursivo do locutor, sem que este renuncie à sua individualidade.

Assim, temos que, apesar de possuírem caraterísticas estruturais semelhantes, os gêneros do discurso são "tipos relativamente estáveis de enunciados" (Id., 2003, p. 262), ou seja, não temos uma total estabilidade desses tipos, mas sim uma relativa estabilidade.

Dessa forma, temos a possibilidade de considerar "que não é a estrutura genérica, a forma pré-estabelecida que funda um gênero discursivo, mas o seu uso e a sua função na sociedade e no campo de utilização (BUIN; CONCEIÇÃO, no prelo, p. 2), tendo, assim, a necessidade de rever como têm sido trabalhados os gêneros na educação básica, já que presenciamos, em muitos casos, o ensino de gêneros discursivos como modelos a serem seguidos pelos alunos durante a produção de textos (AZEVEDO, 2006). Sobre essa questão, Buin e Conceição (no prelo, p. 3) chamam a atenção para o fato de que

\begin{abstract}
o estudo da forma, geralmente, tem precedido (para não dizer substituído) o da função. Em muitos casos, há apenas uma substituição do conteúdo tido como tradicional e desatualizado (os exercícios de estruturas gramaticais) pelo exercício fundado no estudo da estrutura de diferentes gêneros. Tão nocivo quanto o ensino de estruturas linguísticas descontextualizadas é o ensino dos gêneros sem que lhe seja dado um significado para os aprendizes. Em outros termos, e em muitos casos, o ensino de língua parece continuar a padecer dos mesmos males, apesar das mudanças propaladas.
\end{abstract}

Concebendo a produção de textos sem levar em conta as relações intergenéricas, o gênero do discurso é considerado como "produto, uma vez que enxerga como simples desarticulações ou inconsistências aspectos que resultam, mais propriamente, do trânsito de práticas sociais e históricas" (CÁLIS, 2015, p. 14). Além disso, a escrita parece ser destituída do social, não sendo considerada como deveria, ou seja, como uma "prática social", pois não é levado em conta que, ao utilizar a linguagem, os sujeitos refletem nela o que lhes é próprio, como seus valores, suas crenças, suas ideologias, por exemplo (SILVA, 2002).

No entanto, se concebermos as relações que os gêneros discursivos podem estabelecer com outros gêneros, a escrita passa a ser compreendida "como processo, [...] não como produto, mas uma etapa, um momento do fluxo da linguagem [...]" (Ibid., no prelo, p. 10). Nas palavras de Buin e Conceição (no prelo, p. 11),

DOI: https://doi.org/10.32988/rep.v10n1.1561

Dossiê "Possibilidades de trabalho com a Língua Portuguesa"

\begin{tabular}{|l|c|c|c|c|c|c|} 
Revista (Entre Parênteses) & Alfenas, MG & v. 10 & n. 1 & $1-33$ & e021013 & 2021 \\
\hline
\end{tabular}




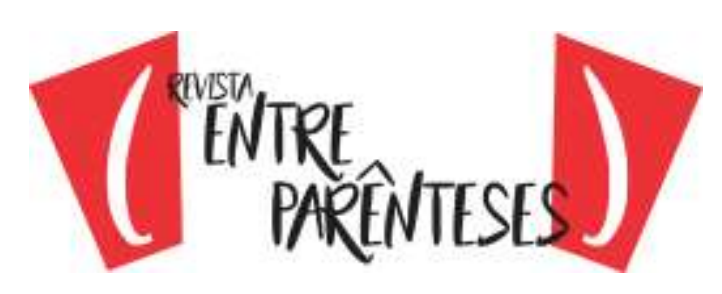

ISSN 2238-4502

A escrita não é dada como algo acabado, mas parte do próprio processo de aquisição da linguagem [...] Ela não tem uma unidade de acontecimento, pois não se trata de um produto acabado; não tem unidade de ato, pois é tomada na situação dialógica e não como produto de um indivíduo fonte; não se limita ao próprio texto, uma vez que este não é autossuficiente em suas relações internas.

Partindo dessa perspectiva, o texto produzido pelo aluno não tem mais um caráter de modelo, muito menos de um produto, 'mas [...] [de] 'um ponto' de uma rede de relações maiores, uma cena congelada do fluxo da linguagem, no processo social da interação verbal" (Ibid., no prelo, p. 11). Assim, com base na noção das relações intergenéricas, entendemos que as ruínas presentes no texto do aluno, ou seja, aquelas marcas que podem nos indicar essas relações, podem evidenciar tentativas de inserção desse sujeito nas práticas letradas a que está sendo submetido. Corrêa (2006, p. 210), a esse respeito, comenta que as ruínas,

quando consideradas como fragmentos de enunciados genéricos, [...] podem ser vistas, também, como o resultado de uma 'regeneração', pensada esta última como o processo pelo qual os sinais de um conjunto de saberes (as ruínas de uma civilização!) podem assumir o papel de elementos fundadores de novos saberes.

0 autor alerta para esse fato, pois admite que, ainda hoje, tem-se a prática de levar em consideração, no texto do aluno, somente aquilo que poderia ser concebido como um erro ou que estivesse fora dos padrões estabelecidos, ressaltando que:

Durante muito tempo (e está longe de ser uma prática antiga!), o professor empenhouse muito mais em buscar vestígios de erros, no sentido normativo, do que em reconhecer algum significado para as supostas inconsistências de seu aluno. E revelouse sempre um exímio caçador (e punidor) de variedades estigmatizadas, de supostas inadequações a situações de uso, de regionalismos, de gírias, de discrepâncias entre usos orais e usos escritos da língua. (Corrêa, 2009, p. 209-210)

Por isso, defendemos, assim como autor, "que o leitor (o professor, no caso) seja capaz de propor, de modo pertinente, a descoberta de uma ruína de gênero discursivo onde se via apenas vestígio de erros e inadequações" (Id., 2006, p. 210). Assim, chamamos a atenção para o fato de não considerar as ruínas como algo ruim, mas como algo produtivo que é, de certo modo, intrínseco à construção dos gêneros discursivos. Dessa forma, estamos propondo a utilização de um modelo de letramentos acadêmicos, proposto por Lea e Street (2006), que está relacionado à "produção de sentido, identidade, poder e autoridade" (LEA; STREET, 2006, p. 1), em detrimento de outros dois modelos, o de habilidades de estudo e o de socialização acadêmica, que têm, segundo os autores, feito parte das propostas pedagógicas, dos currículos e também de pesquisas. Em relação a esses outros dois modelos propostos pelos autores, o

DOI: https://doi.org/10.32988/rep.v10n1.1561

Dossiê "Possibilidades de trabalho com a Língua Portuguesa"

\begin{tabular}{|l|c|c|c|c|c|c|}
\hline Revista (Entre Parênteses) & Alfenas, MG & v. 10 & n. 1 & $1-33$ & e021013 & 2021 \\
\hline
\end{tabular}




\section{(")}

ISSN 2238-4502

primeiro, o de habilidades de estudo está relacionado aos "aspectos da superfície da forma da língua" (Ibid., 2006, p. 1), ou seja, a ênfase recai sobre o uso da escrita de forma que a superfície é que tenha atenção, e entende que, se o indivíduo consegue utilizar a escrita em determinado contexto, poderá passar esse conhecimento para qualquer outro âmbito, sem ter, com isso, dificuldades. Já o segundo, o de socialização acadêmica, pressupõe que os "estudantes adquirem modos de falar, escrever, pensar e interagir em práticas de letramento que caracterizavam membros de comunidade disciplinar ou temática" (LEA; STREET, 2006, p. 1) e, tendo, com isso, "aprendido e entendido as regras básicas de discurso acadêmico particular, estão aptos a reproduzi-lo sem obstáculo” (Ibid., 2006, p. 1).

Lea e Street (2006) comentam que há uma aproximação entre o modelo de letramentos acadêmicos e o de socialização de habilidades, mas enfatizam que os dois se diferenciam, pois o primeiro modelo considera "os processos envolvidos na aquisição de usos adequados e eficazes de letramento como mais complexos, dinâmicos, matizados, situados" (Ibid., 2006, p. 2). Além disso, leva em consideração de que forma as práticas de letramento de outras esferas "estão comprometidas com aquilo que os estudantes precisam aprender e fazer" (Ibid., 2006, p. 3), ressaltando que "tanto questões epistemológicas quanto processos sociais, inclusive relações de poder entre pessoas, instituições e identidades sociais (Ibid., 2006, p. 2)" entram em jogo.

Ressaltamos a relação com o modelo de letramentos acadêmicos, pois, ao levar em conta outros aspectos, como, por exemplo, o poder e a identidade, esse modelo, conforme citam os autores, "coloca em primeiro plano a variedade e a especificidade das práticas institucionais e a luta dos estudantes para que essas práticas façam sentido" (Ibid., 2006, p. 9). Essa perspectiva nos leva a considerar, por exemplo, a relação entre os textos produzidos pelos alunos em outros contextos com alguns dos que eles vão produzir na esfera universitária como a resenha, por exemplo, na tentativa de se inserirem nas práticas específicas dessa atividade de comunicação humana.

Relacionado a esse modelo, entendemos que os estudantes, ao produzirem as resenhas, fizeram uso dos três elementos que compõem os gêneros do discurso, a saber: o estilo, o conteúdo temático e a construção composicional. Ao utilizarem, porém, esses três elementos fizeram escolhas que ora nos levam a gêneros acadêmicos, ora nos conduzem à redação escolar, gênero com que estão familiarizados e que pode ajudá-los na nova produção.

\section{As práticas de escrita em diferentes contextos: a educação básica e o ensino superior}

No que diz respeito ao trabalho de produção de textos na escola, visto que "a instituição escolar concentrou para si, ao longo dos anos, a missão de preparar os sujeitos para produzir textos de diferentes gêneros [...]" (AZEVEDO, 2006, p. 210), vemos, em muitos casos, que há uma distorção no que diz respeito a esse trabalho, indicando que, apesar de ser trazida para a sala de aula uma variedade de gêneros e de tipos textuais, a escola "tomou-os [...] como

DOI: https://doi.org/10.32988/rep.v10n1.1561

Dossiê "Possibilidades de trabalho com a Língua Portuguesa"

\begin{tabular}{|l|c|c|c|c|c|c|} 
Revista (Entre Parênteses) & Alfenas, MG & v. 10 & n. 1 & $1-33$ & e021013 & 2021 \\
\hline
\end{tabular}




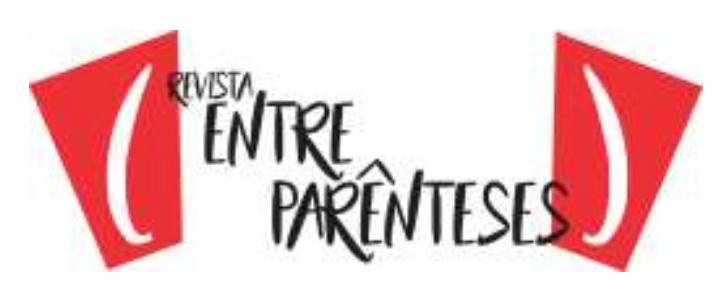

ISSN 2238-4502

modelos ou protótipos a serem seguidos pelos (re)produtores e não apenas como ponto de partida para a leitura/produção de textos" (Ibid., 2006, p. 210).

Tal fato nos mostra que a atenção do professor no que diz respeito ao texto do aluno está, muitas vezes, direcionada a verificar se o texto produzido está adequado ao modelo apresentado. Em relação a isso, Cális (2015, p. 13) comenta que

o ensino de um gênero discursivo em nossas salas de aula (quando ocorre) procura focalizar tão-somente se os textos produzidos pelos alunos correspondem aos modelos apresentados pelos professores, o que se traduz, na maioria dos casos, na mera verificação dos aspectos formais presentes nesses textos.

Dessa forma, preocupado com a avaliação que vai receber do professor, percebemos que o aluno, em muitos momentos, oscila "entre o que [...] deveria escrever, respeitando o modelo imposto pela escola, e o que [...] efetivamente queria escrever" (SOARES, 2003 apud CAPRISTANO; OLIVEIRA, p. 20, 2014). Essa situação agrava-se conforme o nível de escolaridade vai aumentando, já que, com isso, o aluno vai tendo mais contato com as práticas de escrita escolares, deixando, assim, menos marcas ou pistas do que "efetivamente queria escrever". Tal fato faz com que a escrita do aluno vá se configurando, cada vez mais, como uma produção que segue um modelo predeterminado (Ibid., 2006) o qual apresenta poucos traços do escrevente e que, muitas vezes, quanto mais ao gosto do professor estiver, mais probabilidade de sucesso (de uma boa nota) o aluno parece poder garantir.

Para entendermos melhor o trabalho que é normalmente realizado na escola acerca da produção do gênero redação escolar, será feita, nesta seção, uma análise de dois materiais ${ }^{8}$ disponíveis na Internet que indicam ter como objetivo ensinar como se produz um texto do tipo dissertativo-argumentativo, o que denominamos "redação escolar". Além disso, serão analisados também dois materiais que tratam do gênero discursivo resenha a fim de compreendermos melhor como ele é concebido na universidade. ${ }^{9}$ Logo no início de um dos materiais sobre a redação escolar, a confusão entre gênero e tipo textual é evidenciada, pois o primeiro conceito que aparece é o de "Dissertação", indicando que

Dissertar é discutir assuntos, debater ideias, tecer opiniões, delimitando um tema dentro de uma questão ampla e defendendo um ponto de vista, por meio de argumentos convincentes. É um tipo de texto lógico-expositivo - colocamo-nos criticamente perante

\footnotetext{
${ }^{8}$ Os materiais que serão analisados foram encontrados na Internet, por meio do site de busca Google, a partir da seguinte expressão "redação dissertação pdf". Os materiais encontram-se disponíveis em: http://www.ensino.alexanderfleming.com.br/figuras/projensfund58/Disciplinas/2010/LIP/2Bim/O Estudo te xto Dissertativo 9ano.pdf

http://www.filoczar.com.br/Conteudo\%20educacional/Apostilas/Redacao/Dissertacao.pdf.

${ }^{9}$ Os materiais em relação à resenha foram retirados de dois livros que se referem à produção de textos acadêmicos, ou seja, à produção escrita no contexto universitário.
}

DOI: https://doi.org/10.32988/rep.v10n1.1561

Dossiê "Possibilidades de trabalho com a Língua Portuguesa"

\begin{tabular}{|c|c|c|c|c|c|c|} 
Revista (Entre Parênteses) & Alfenas, MG & v. 10 & n. 1 & $1-33$ & e021013 & 2021 \\
\hline
\end{tabular}




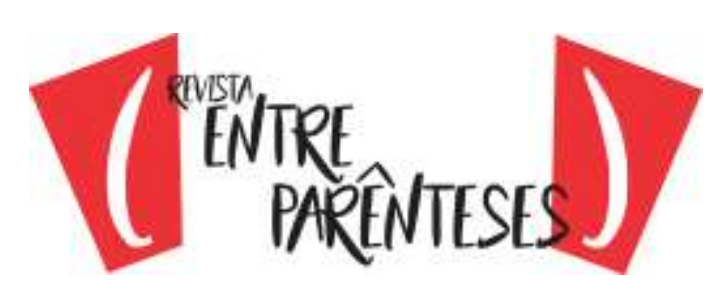

ISSN 2238-4502

alguma dimensão da realidade e, mais do que isso, fundamentamos nossas ideias; explicitamos os motivos pelos quais pensamos o que pensamos (p. 1).

Podemos perceber que, além de evidenciar o conceito de dissertação, o trecho apresentado destaca também como deve ser produzido esse tipo de texto, em que o aluno, para discutir sobre determinado assunto, deve delimitar o tema e utilizar "argumentos convincentes" para defender seu ponto de vista. 0 outro material não apresenta um conceito de texto dissertativo-argumentativo. Parece pressupor que o aluno já conhece esse tipo de texto e, por isso, já inicia com as dicas de como produzi-lo. A ênfase na produção de um modelo que deve ser seguido pelo aluno permeia os dois materiais e parece ficar evidente que, para escrever um bom texto do tipo dissertativo-argumentativo, é necessário encaixar as ideias num esquema, que se constitui por Introdução, Desenvolvimento e Conclusão. É garantida ainda mais ênfase ao modelo quando ambos os materiais explicitam as formas de se escrever uma Introdução, como se houvesse a necessidade de deixar claro para o estudante quais as maneiras possíveis de se escrever essa parte do texto. Nos dois materiais, fica evidente a necessidade de o aluno atentar-se para a quantidade de linhas e de parágrafos que o texto deve possuir. Em um deles, esse aspecto parece ser tão importante que é apresentada, logo na primeira página, a quantidade de parágrafos e de linhas: ${ }^{10}$

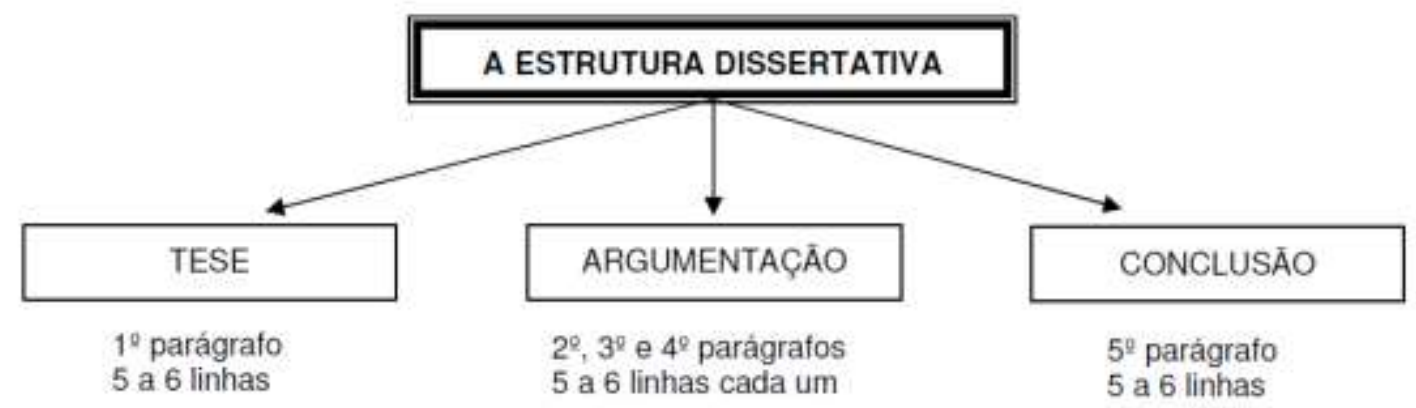

Em um dos materiais, a seção intitulada "Apresentação da Redação" prescreve como devem ser os parágrafos do tipo de texto dissertativo-argumentativo, indicando que o aluno não possui autonomia para escrever como quer, isto é, ele é cerceado de todas as formas possíveis:

Parágrafos: devem adentrar a linha dois centímetros e iniciarem-se sempre à mesma altura. 0 número de parágrafos varia de acordo com a extensão da redação. Procure

10 A figura foi retirada do material que se encontra disponível em: http://www.ensino.alexanderfleming.com.br/figuras/projensfund58/Disciplinas/2010/LIP/2Bim/O_Estudo_te xto_Dissertativo_9ano.pdf

DOI: https://doi.org/10.32988/rep.v10n1.1561

Dossiê "Possibilidades de trabalho com a Língua Portuguesa"

\begin{tabular}{|l|l|l|l|l|l|l} 
Revista (Entre Parênteses) & Alfenas, MG & v. 10 & n. 1 & $1-33$ & e021013 & 2021 \\
\hline
\end{tabular}




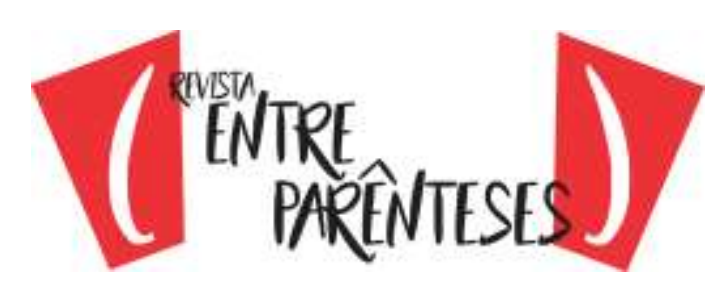

ISSN 2238-4502

fazer o mínimo de três parágrafos; o máximo dependerá do número de linhas pedidas. Não faça parágrafos muito extensos para evitar mistura de ideias. Apenas o primeiro parágrafo pode ser constituído de um período (p. 4).

Para se ensinar a Introdução e a Conclusão, em ambos os materiais, são utilizados exemplos dos tipos possíveis de se introduzir e de concluir um texto. No que diz respeito ao Desenvolvimento, em um dos materiais, não são explicitadas as formas pelas quais os alunos podem desenvolver o tema, são só indicados dois exemplos. Já no outro material, o Desenvolvimento recebe o nome de Argumentação e, por isso, há uma explicitação das formas de argumentar em um texto. Em relação à Conclusão, um dos materiais parece inovar quando afirma que "não há um modelo único de conclusão. Cada texto pede um determinado tipo de fechamento, a depender do tema, bem como do enfoque escolhido pelo autor" (p. 14), mas retrocede ao modelo, logo em seguida, quando indica que, "em textos com teor informativo, por exemplo, caberá a conclusão que condense as ideias consideradas. Já no caso de textos cujo conteúdo seja polêmico, questionador, será apropriada uma conclusão que proponha soluções ou trace perspectivas para o tema discutido" (p. 14).

No que diz respeito ao gênero resenha, Motta-Roth e Hendges (2010) afirmam que é um gênero discursivo utilizado no contexto acadêmico que "serve para incrementar o diálogo acadêmico entre pesquisadores [...]" (MOTTA-ROTH; HENDGES, 2010, p. 45), uma vez que se presta a "avaliar - elogiar ou criticar - o resultado da produção intelectual em uma área do conhecimento" (Ibid., 2010, p. 27). Sem levar em consideração a noção de gênero discursivo, Oliveira (2009, p. 113) caracteriza a resenha como um "resumo crítico ou recensão", o que faz com que, no processo de produção desse texto, segundo o autor (2009, p. 113), possa se seguir os mesmos passos utilizados na elaboração de um resumo, acrescentando somente uma apreciação crítica sobre o produto que está sendo resenhado. No que diz respeito à extensão desse gênero discursivo, Motta-Roth e Hendges (2010) observam que, se comparada a outros textos da academia, como um artigo ou uma tese, a resenha é mais curta. Além disso, a linguagem utilizada "frequentemente inclui verbos no presente do indicativo para descrever a atualidade e a relevância do tema do livro [...] e para descrever a organização do livro [...] e para avaliá-lo (Ibid., 2010, p. 43), bem como "é densamente avaliativa e, muitas vezes, inclui exemplos ou excertos do livro para ilustrar críticas ou elogios" (Ibid., 2010, p. 43).

Pela conceituação, Motta-Roth e Hendges (2010) vão além de considerar a resenha como um simples resumo, trazendo, além da questão da apreciação crítica, outros aspectos a serem contemplados. Para as autoras (2010), os objetivos do escrevente e do leitor de uma resenha são diferentes: o primeiro é o responsável por repassar sua leitura e avalição da obra, ao passo que o segundo é aquele que busca essas informações. Motta-Roth e Hendges comentam que

Para atender ao leitor, o resenhador basicamente descreve e avalia uma dada obra a partir de um ponto de vista informado pelo conhecimento produzido anteriormente

DOI: https://doi.org/10.32988/rep.v10n1.1561

Dossiê "Possibilidades de trabalho com a Língua Portuguesa"

\begin{tabular}{l|l|l|l|l|l|l} 
Revista (Entre Parênteses) & Alfenas, MG & v. 10 & n. 1 & $1-33$ & e021013 & 2021 \\
\hline
\end{tabular}




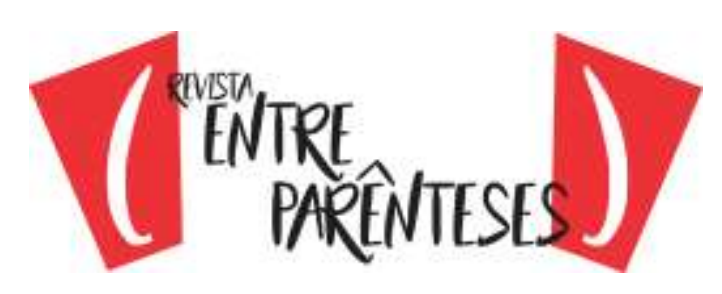

ISSN 2238-4502

sobre aquele tema. Seus comentários devem se conectar com a área do saber em que a obra foi produzida ou com outras disciplinas relevantes para o livro em questão. ( (2010, P. 27-28)

Em relação à utilização da resenha no meio acadêmico, as autoras (2010) comentam que o uso frequente ou não desse gênero discursivo depende muito da área de conhecimento. Citam, por exemplo, que, na área de Letras, em Linguística Aplicada, resenhar livros é uma prática muito mais comum do que em outras disciplinas, como a Física.

No que diz respeito à composição desse gênero discursivo, Oliveira (2009) cita uma estrutura que seria considerada básica para uma resenha, elencando os seguintes aspectos:

- Referência bibliográfica: autor, título da obra, número da edição, local de publicação, editora, ano, e número de páginas;

- Credenciais da autoria: breve apresentação do(a) autor(a) ou autores, em especial quanto ao seu currículo profissional (nacionalidade, áreas de atuação, publicações, formação acadêmica, títulos que possui...);

- Resumo da obra: expor sobre o assunto da resenha, como ele é tratado, metodologia ou estruturação da obra e suas noções básicas. Não se exige que o texto do resumo da obra possua apenas um parágrafo;

- Conclusões do autor: expor com clareza os resultados alcançados pelo autor da obra ou texto resenhado;

- Quadro de referência do autor: se observado esse aspecto, informar qual teoria serve de apoio às ideias do autor da obra;

- Apreciação crítica do resenhista: o estilo do autor é objetivo, conciso? As ideias são originais, claras e coerentes? 0 autor é idealista? Realista?

- Indicações da obra: informar a que público se destina a obra ou a quem ela pode ser útil, como, por exemplo, alunos de determinados cursos, professores, pesquisadores, especialistas, técnicos ou público em geral. Em que curso pode ser adotada? (OLIVEIRA, 2009, p. 114) (Adaptado)

Motta-Roth e Hendges (2010), no entanto, não utilizam esse esquema. ${ }^{11}$ Apontam, ao contrário, que, para produzir uma resenha (no caso, citam especificamente a resenha de livros), é necessário o desenvolvimento de quatro etapas, em que são realizadas as seguintes ações: Apresentar > Descrever > Avaliar > (Não) Recomendar o livro (MOTTA-ROTH; HENDGES, 2010, p. 29). As autoras citam também a possibilidade de existência, em uma resenha, da "descrição de material extra que vai além do texto principal de cada capítulo do

${ }^{11}$ As autoras afirmam que "[é] importante frisar que o uso dos quatro estágios textuais [...] foi uma evidência verificada em periódicos internacionais (Motta-Roth, 1996). Portanto, a descrição do gênero nesses termos deve ser tomada como uma constatação de como as pessoas escrevem resenhas em determinado espaço geográfico [...], e não uma norma a ser seguida cegamente" (MOTTA-ROTH; HENDGES, 2010, p. 29).

DOI: https://doi.org/10.32988/rep.v10n1.1561

Dossiê "Possibilidades de trabalho com a Língua Portuguesa"

\begin{tabular}{|c|c|c|c|c|c|c|} 
Revista (Entre Parênteses) & Alfenas, MG & v. 10 & n. 1 & $1-33$ & e021013 & 2021 \\
\hline
\end{tabular}




\section{(")}

ISSN 2238-4502

livro, na forma de apêndices, anexos, tabelas, gráficos [...]" (Ibid., 2010, p. 36), chamando a atenção para o fato de que a forma e também a frequência da descrição desses materiais em uma resenha dependem muito da área a que pertence o produto resenhado, bem como da temática desse produto. Assim, temos que esses aspectos "serão mencionados sempre que isso for relevante para a avaliação do livro ou para as práticas de publicação da disciplina” (Ibid., 2010, p. 36).

Dessa forma, vemos que, de um material para o outro, além da diferença de conceituação do gênero resenha, a forma como os autores encaram a produção desse gênero parece também ser diferente. Oliveira (2009) volta-se mais à estrutura do texto, isto é, quando for produzir uma resenha, o aluno deve se atentar à estrutura composicional. Tentando relacionar com a prática de produção de textos na educação básica, é básica e ordinariamente o que acontece com o ensino do gênero redação escolar: a ideia de que, para produzir bem determinado texto, o aluno precisa condicionar sua escrita às regras de composição, ou seja, à estrutura convencionada a esse gênero. Essa posição parece se diferenciar da exposta por Motta-Roth e Hendges (2010), uma vez que as autoras deixam claro que a extensão e a frequência das ações citadas vão variar conforme o resenhador e também o produto que está sendo resenhado.

Assim, como defendemos que, na produção de determinado gênero, pode haver ruínas de outros gêneros, entendemos que as ideias de Motha-Roth e Hendges (2010), ao darem menor importância à estrutura e mais ao que será escrito, são as que nos interessam nesta pesquisa. Consideramos que a estrutura não deve ser esquecida, no entanto problematizamos que, se a atenção estiver voltada apenas para a estrutura composicional, os textos produzidos pelo escrevente poderão se tornar padronizados em função do modelo imposto ou proposto pelo professor, considerado o único leitor do texto do escrevente, e não em função de seu projeto enunciativo. Tais aspectos indicam a necessidade de o produtor fazer escolhas em relação ao ato de escrever, evidenciando, assim, que o uso da linguagem não se resume à adequação à determinada situação comunicativa, isto é, não se limita a ela, mas sempre será uma opção do sujeito que escreve em função do próprio gênero do discurso, da esfera de atividade humana e de seu projeto enunciativo.

\section{Possíveis contribuições de Bakhtin para o ensino de escrita}

Ao discutirmos esses pressupostos, percebemos uma diferenciação em relação a como trabalhar com a linguagem, em contextos de ensino de língua(gem). Ao estabelecer uma diferenciação entre linguagem, língua e fala, em que a linguagem é "a faculdade, própria do ser humano, de produzir sentido" (CORRÊA, 2002, p. 22), a língua, "produto da capacidade humana de produzir signos e arranjá-los em sistemas" (Ibid., 2002, p. 22) e a fala, "que se restringe ao âmbito do falante e de suas capacidades e idiossincrasias" (Ibid., 2002, p. 22), Saussure estabelece como objeto de estudo da linguística a língua, uma vez que entende a fala como "a

DOI: https://doi.org/10.32988/rep.v10n1.1561

Dossiê "Possibilidades de trabalho com a Língua Portuguesa"

\begin{tabular}{|l|l|l|l|l|l|l|}
\hline Revista (Entre Parênteses) & Alfenas, MG & v. 10 & n. 1 & $1-33$ & e021013 & 2021 \\
\hline
\end{tabular}




\section{("ENTRE}

ISSN 2238-4502

execução solitária desse processo coletivo de significação do mundo [da língua]" (Ibid., 2002, p. 22), ou seja, que é particular e que não está relacionada à utilização coletiva. Corrêa ressalta que, ao privilegiar o estudo da língua, Saussure não exclui a linguagem, pois "é o estudo da capacidade de criar signos e ordená-los num sistema que está na base de sua reflexão" (Ibid., 2002, p. 22).

Ao considerar a língua como um produto humano, ressalta-a, conforme afirma Corrêa (2002, p. 25), "como uma instituição social" que se caracteriza "como um meio para se chegar a um certo fim [...] como meio dirigido ao fim da comunicação no interior de um grupo humano" (Ibid., 2002, p. 25), assim, temos a língua como instrumento de comunicação, em que são desconsideradas, por exemplos, as relações de poder que aparecem na comunicação e que regulam, de certo modo, a convivência social (Ibid., 2002). Além disso, Saussure adota uma concepção de língua homogênea e que se restringe a um sistema, conforme aponta Corrêa (2002). Dessa forma, desconsidera a fala "que teria como preocupação a ação do indivíduo e dos grupos no interior de uma sociedade" (Ibid., 2002, p. 26), renegando, portanto, “a heterogeneidade conflitiva registrada na língua" (Ibid., 2002, p. 26).

Saussure, ao adotar uma concepção em que não se considera a heterogeneidade da língua, trabalha com algo fechado, com uma espécie de sistema e, com isso, desconsidera o falante, já que, se fosse considerá-lo, a suposta homogeneidade da língua não existiria. Desse mesmo modo, trabalham alguns professores quando, ao ensinar a escrita, utilizam, para tal, modelos prontos a serem seguidos, em sua quase totalidade, pelos alunos na produção de um gênero. Assumir essa postura é desconsiderar que o sujeito pode adotar o que for mais conveniente em sua produção, já que é necessário levar em conta o intuito discursivo, a esfera em que se encontra e o interlocutor. Assim, não há como negar que, ao assumir essa postura, o trabalho com a escrita toma outros rumos. 0 texto deverá ser concebido como processo e, como tal, demandará tempo para ser produzido, bem como mais esforço do professor para orientar esse processo de escrita-reescrita do texto.

Bakhtin, trazendo posições diferentes em relação às propostas por Saussure e também por outros estudiosos, como Benveniste, considera a linguagem em sua relação dialógica, afirmando que "todo enunciado está marcado pela história de suas ocorrências", tendo, assim, em todo enunciado, "um acúmulo de vozes" (CORRÊA, 2002, p. 67). Nesse sentido, aparece a imagem do enunciado concreto, ou seja, que é uma unidade real, e não convencional da língua (Ibid., 2002, apoiando-se em Bakhtin). Segundo Corrêa (2002), na visão de Bakhtin, sempre que formos utilizar a língua, será por meio desses enunciados que podem ser escritos ou orais que são compostos pelo estilo, pelo conteúdo temático e pela construção composicional. Assim, "os modos de utilização da língua dão uma natureza comum aos enunciados - a dos gêneros do discurso a que pertencem" (Ibid., 2002, p. 67). Além disso, algo importante a se considerar em relação ao enunciado diz respeito à demarcação de suas fronteiras que "se dá pela alternância dos sujeitos falantes", ou seja, limitada pela "presença do outro” (Ibid., 2002, p. 67).

DOI: https://doi.org/10.32988/rep.v10n1.1561

Dossiê "Possibilidades de trabalho com a Língua Portuguesa"

\begin{tabular}{|l|l|l|l|l|l|l} 
Revista (Entre Parênteses) & Alfenas, MG & v. 10 & n. 1 & $1-33$ & e021013 & 2021 \\
\hline
\end{tabular}




\section{(")}

ISSN 2238-4502

Ao ser demarcado por essa alternância de sujeitos, Bakhtin considera que o acabamento do enunciado é um fato importante a se levar em conta, pois "o limite do enunciado, a sua ideia de totalidade, o seu acabamento [...] está ligado à abertura para o ouvinte e não ao fechamento em uma estrutura [...]" (Ibid., 2002, p. 68). No entanto, Corrêa (2002, p. 68) comenta que a delimitação do enunciado não se restringe "à presença física do outro", uma vez que é possível que essa presença se dê, por exemplo, "no interior de um único e mesmo enunciado" (Ibid., 2002, p. 69).

Desse modo, ressalta-se a relação que pode ser estabelecida entre os gêneros do discurso. Segundo Corrêa (2002, p. 69), eles "não são formas linguísticas fechadas, estão submetidos a relações intergenéricas", que nos indicam uma abertura no limite dos gêneros. São essas relações intergenéricas, de que trata Corrêa (2002), que devem ser consideradas na produção de textos, uma vez que "muitas das desarticulações percebidas em um texto ou das inconsistências em sua leitura são produto de passagens (mal construídas ou mal percebidas) de um gênero a outro" (Ibid., 2002, p. 69). Ademais, como se refere o autor, quando trabalhamos numa perspectiva de que ensinar a produção de determinado gênero é prescrever um modelo a ser seguido, há a negação da "mobilidade das relações intergenéricas" (Ibid., 2002, p. 69). Dessa forma, percebemos que não há espaço para se considerar a relação entre os gêneros, uma vez que o importante é seguir o modelo imposto ou proposto pelo professor.

Ruínas do gênero redação escolar em resenhas

Conforme concebemos, ao produzir determinado gênero, principalmente um que o sujeito ainda não domina, o escrevente pode se valer de outros a fim de que os conhecimentos que ele já possui possam ajudá-lo a compor um texto com o qual ainda não tem familiaridade. Dessa forma, um gênero discursivo sempre está sujeito às relações intergenéricas, mostrando que o ensino de gêneros discursivos baseado somente na estrutura e em um modelo a ser seguido deve ser repensado. Assim, muitos aspectos que já são conhecidos e utilizados pelos alunos na produção de textos, conhecimentos que muitos devem ter adquirido durante educação básica, fazem-se presentes na produção de textos que eles ainda não dominam. Um exemplo disso relaciona-se à produção de uma resenha no contexto universitário que se diferencia de uma resenha produzida na educação básica por apresentar alguns aspectos característicos da esfera acadêmica. Ainda que o contato com esse gênero na educação básica seja bem pequeno e a resenha produzida no ambiente universitário seja distinta da que ele conheceu na escola, o aluno, ingressante em um curso superior, quando for produzir esse texto, pode se valer do conhecimento da resenha ensinada na escola, mas também de outros gêneros para essa produção.

A análise do corpus evidencia que, para produzir o gênero resenha, tido como novo, os graduandos utilizam características dos gêneros redação escolar e redação do Enem, muito produzidos no ensino médio. Dentre essas características, percebemos uma recorrência da

DOI: https://doi.org/10.32988/rep.v10n1.1561

Dossiê "Possibilidades de trabalho com a Língua Portuguesa"

\begin{tabular}{|l|l|l|l|l|l|l|} 
Revista (Entre Parênteses) & Alfenas, MG & v. 10 & n. 1 & $1-33$ & e021013 & 2021 \\
\hline
\end{tabular}




\section{(")}

ISSN 2238-4502

presença de uma estrutura de quatro ou cinco parágrafos, recomendada na produção da dissertação de vestibular/redação do Enem. Tal estrutura é ainda mais reforçada quando é solicitada aos alunos, no primeiro parágrafo, a presença da tese na introdução, nos outros dois, o desenvolvimento da tese expressa na introdução, e no último, a conclusão, ou seja, um parágrafo que retome a tese defendida. Além da conservação da estrutura, em muitas resenhas, foi percebida também a presença de uma tese em relação ao assunto do texto lido, indicando uma opinião sobre o exposto no artigo lido para a produção da resenha.

Para exemplificar a presença do gênero dissertação/redação do Enem, transcrevemos parte de uma resenha em que esse aspecto fica mais evidente. A resenha apresenta essa estrutura duas vezes, assim, o texto parece se constituir de Tese/Desenvolvimento/Conclusão (1 $1^{\underline{a}}$ ocorrência) e Tese/Desenvolvimento/Conclusão (2 $2^{\underline{a}}$ ocorrência). A título de exemplificar como se dá essa estrutura, citamos a sua segunda ocorrência em uma resenha: ${ }^{12}$

Rojo mostra em seu texto os desafios que o multiletramento enfrenta e os estudos de Bakhtim para conciliar o letramento tradicional com o multiletramento.

Hoje o mundo exige muito mais que apenas o ensinamento que é restrito aos muros da escola, o conhecimento passado aos alunos devem ultrapassar esse muros e ir de encontro ao mundo onde estes conhecimentos farão sentido, terão significância.

O mundo está cada vez mais competitivo e é obrigação da escola como instituição de ensino preparar o educando para enfrentar os obstáculos que encontrará na vida sabendo utilizar das diversas habilidades que desenvolverá em sua trajetória escolar. (ALUNO 14G)

Percebemos que o escrevente apresenta sua tese, indicando que o texto lido retrata os desafios dos multiletramentos ("Rojo mostra [...] os desafios que o multiletramento enfrenta") e se vale de outros estudos, como os de Bakhtin ("os estudos de Bakhtim para conciliar o letramento tradicional com o multiletramento"), para defender o ponto de vista expresso. Após isso, o escrevente desenvolve o assunto ("Hoje o mundo exige muito mais que apenas o ensinamento que é restrito aos muros da escola"), indicando a necessidade de se repensar o modo como o ensino é trabalhado para, então, evidenciar a importância de a escola preparar o estudante para a vida. Ao trazer a ideia de que aquilo que é ensinado ao aluno na escola precisa ser útil à vida, uma outra tentativa por parte desse escrevente pode se fazer presente, a de que ele já tomou contato com documentos oficiais do ensino de Língua Portuguesa e que, por isso, para se mostrar um sujeito familiarizado com as práticas de escrita da universidade, utiliza-se dessa ideia.

Além disso, retomando os pontos de contato com as práticas de escrita da educação básica, um aspecto muito recorrente diz respeito ao modo de apresentação de uma conclusão, em que, por meio de poucas linhas, o escrevente encerra seu texto retomando a opinião

12 Este texto resenha o artigo “Gêneros discursivos do círculo de Bakhtin e multiletramentos”, de Roxane Rojo.

DOI: https://doi.org/10.32988/rep.v10n1.1561

Dossiê "Possibilidades de trabalho com a Língua Portuguesa"

\begin{tabular}{|l|l|l|l|l|l|l|} 
Revista (Entre Parênteses) & Alfenas, MG & v. 10 & n. 1 & $1-33$ & e021013 & 2021 \\
\hline
\end{tabular}


defendida. Esse fechamento, nas resenhas analisadas, ora ocorre de modo a retomar o que é exposto no texto, ora, de modo inesperado, a apresentar uma intervenção para o que estava sendo discutido no artigo lido e que apareceu também na resenha. No caso do trecho apresentado, percebemos que, ao construir a frase "é obrigação da escola como instituição de ensino preparar o educando para enfrentar os obstáculos que encontrará na vida", o escrevente indica uma proposta para a solução do problema exposto. 0 aparecimento de uma proposta de intervenção social remete-nos a um gênero redação do Enem. A intervenção é uma das competências avaliadas no Enem, ou seja, o aluno/candidato precisa demonstrar possíveis formas de se solucionar a problemática indicada no tema da redação (BRASIL, 2013).

Em uma outra resenha, ${ }^{13}$ em que o escrevente trata das práticas de mistério que envolvem a escrita na academia, podemos perceber a conclusão nos moldes de um texto dissertativo tradicional, conforme se observa neste trecho:

É claro que toda a complexidade na fala e escrita dos docentes desta instituição é proposital, já que uma parte de seus alunos não foi privilegiada como a outra no letramento e a dificuldade na comunicação e interação confere melhor "status" aos professores. Assim, suas vozes predominam e determinam todas as tarefas, sem dar chance de diálogo às alunas para realizarem seus trabalhos. Desta forma, o curso acaba não sendo bem aproveitado... (ALUNO5A)

Nesse parágrafo, percebemos que o escrevente recorre a alguns recursos a fim de atingir uma progressão que dirige o leitor à finalização do texto. Dessa forma, inicia o trecho apresentando uma ideia (bem evidente pelo uso da expressão "É claro que") que resume o que foi comentado na resenha e, ao mesmo tempo, indica sua opinião sobre o assunto para depois, ao utilizar "Assim" e "Desta forma", encaminhar o leitor ao encerramento de seu texto.

Em relação à presença de uma conclusão que evidencie uma proposta de intervenção para o problema, num artigo em que a temática era analisar o discurso de policiais em manifestações ocorridas no Brasil, um dos escreventes, para evidenciar a necessidade de resolução do problema, em sua resenha, ${ }^{14}$ indica:

Com a crise da educação pública e com a crise política e social que hoje o país enfrenta, nós, que somos universitários e temos alguma chance, devemos lutar para tentar fazer que no futuro, somente os que sejam realmente aptos, não de poder capitalista, mas de humildade e potencial estejam em frente da cadeira que nos representa. Disseram-me uma vez que linguagem é poder, e é desse poder que precisamos. (ALUNO 16J)

\footnotetext{
13 Este texto resenha o artigo "De quem é o senso comum? O letramento nas redações e instituições do mistério", de Theresa Lillis.

14 Este texto resenha o artigo "Análise crítica do discurso de pronunciamentos da polícia militar durante manifestações populares”, de Micheline Mattedi Tomazi.
}

DOI: https://doi.org/10.32988/rep.v10n1.1561

Dossiê "Possibilidades de trabalho com a Língua Portuguesa"

\begin{tabular}{|l|l|l|l|l|l|l|}
\hline Revista (Entre Parênteses) & Alfenas, MG & v. 10 & n. 1 & $1-33$ & e021013 & 2021 \\
\hline
\end{tabular}




\section{(")}

ISSN 2238-4502

contemplada na prova de redação. Tal proposta indica a necessidade de esse aluno (e também candidato a uma vaga na universidade) estar atualizado aos acontecimentos que o cercam, bem como ser um sujeito que reflete sobre sua realidade, sendo capaz de propor soluções aos problemas existentes.

A presença da proposta de intervenção nos exemplos apresentados evidencia a tentativa de inserção do escrevente em práticas de escrita até então desconhecidas para ele. Essa tentativa pode ter sido utilizada pelo fato de o escrevente ter pensado que, se a apresentação da proposta de solução na redação do Enem fez com que ingressasse em uma universidade, poderia também fazê-lo alcançar seu objetivo na produção de um texto com o qual ainda não possui muito (ou, em alguns casos, nenhum) contato.

\section{Tentativa de inserção nas práticas de escrita do contexto acadêmico}

Ao analisar as resenhas de graduandos dos períodos iniciais de um Curso de Letras, percebemos que esses sujeitos, apesar de ainda não dominarem completamente as 'regras' de como se escrever uma resenha, apresentam já, em seus textos, marcas que podem ser uma tentativa de inserção nas práticas de escrita acadêmica. Um aspecto bem recorrente relacionase ao uso do primeiro nome de um teórico quando o escrevente faz referência a alguma citação implícita ou explícita. É comum, na academia, a utilização de diferentes autores para a construção de seu ponto de vista, como forma de referendar o que está sendo dito pelo autor do texto em processo de produção. Assim, é imprescindível referenciar o teórico utilizado conforme a ABNT (Associação Brasileira de Normas Técnicas). Com base nisso, acreditamos que, quando o escrevente redige o primeiro nome de determinado teórico, mesmo que essa citação não tenha sido feita do modo como é exigido, esse gesto evidencia sua tentativa de inserção nas práticas de escrita do contexto acadêmico.

Para exemplificar, vejamos alguns trechos:

Dóris trata no seu texto [...] (ALUNO2L) ${ }^{16}$

Em seu texto Elzimar nos leva a fazer [...] (ALUNO15B) ${ }^{17}$

No decorrer do texto Brian demonstra [...] (ALUNO2A) ${ }^{18}$

\footnotetext{
16 Este texto resenha o artigo "A estilística da enunciação para o estudo da prosa literária no ensino médio", de Dóris de Arruda C. da Cunha.

${ }^{17}$ Este texto resenha o artigo "Lugar de aprender língua estrangeira é na escola: reflexões em torno do PNLD 2011", de Elzimar Goettenauer de Martins Costa.

18 Este texto resenha o artigo "Perspectivas interculturais sobre o letramento", de Brian Street.
}

DOI: https://doi.org/10.32988/rep.v10n1.1561

Dossiê "Possibilidades de trabalho com a Língua Portuguesa"

\begin{tabular}{|l|c|c|c|c|c|c|} 
Revista (Entre Parênteses) & Alfenas, MG & v. 10 & n. 1 & $1-33$ & e021013 & 2021 \\
\hline
\end{tabular}




\section{(")}

ISSN 2238-4502

Nesses exemplos, em vez de citar o teórico pelo sobrenome, conforme a ABNT, os alunos referenciam o teórico com o primeiro nome, fato que pode nos indicar uma tentativa de inserção nas práticas de escrita acadêmica. Outra hipótese em relação à utilização do primeiro nome pode ser formulada. Os professores da universidade em que os sujeitos de pesquisa deste trabalho estão inseridos já publicaram artigos, capítulos de livros e livros com os quais muitos dos graduandos tiveram contato. Essa hipótese é confirmada quando, em uma das produções em que resenha um texto ${ }^{19}$ de professores da própria universidade, um dos escreventes cita "No texto de Rosângela e Elias" (ALUNO2K). Dessa forma, percebe-se que, familiarizado com seus professores, o escrevente ainda não faz a distinção (ou pelo menos não consegue aplicála) entre o indivíduo que é o seu professor e o pesquisador. No caso da utilização do nome "Elzimar", outra hipótese surge. Os escreventes tiveram a oportunidade de conhecer a pesquisadora num evento na universidade, sentem-se, portanto, familiarizados com ela, o que acaba sendo evidenciado em seus textos.

Apesar de haver a utilização, em alguns momentos, do primeiro nome do autor do texto resenhado para referenciá-lo, em nenhuma das produções do corpus foi percebida a utilização do artigo definido junto ao nome do pesquisador. Observa-se que, mesmo utilizando, por exemplo, "Elzimar", o escrevente utiliza o conectivo "de", e não "da", indicando que, de algum modo, ele tem ideia de algumas regras que regem a escrita acadêmica.

Além disso, um aspecto que envolve algumas características da produção de texto no contexto universitário refere-se à intertextualidade, ou seja, a presença, no texto que está sendo produzido, das vozes de outros autores que podem confirmar, refutar, contradizer as ideias que estão sendo apresentadas pelo escrevente. Essa mobilização pode ser encontrada em algumas resenhas produzidas, evidenciando que, apesar de não dominarem totalmente o gênero que precisa ser produzido, os escreventes tentam utilizar alguns dos aspectos que fazem parte dele.

Essa marca fica bastante evidente nos seguintes trechos:

O fato de tratar os discursos de poder, me fez pensar que a sociedade contemporânea está firmada, sob vários ângulos, na teoria darwiniana de "seleção natural", na qual, segundo Darwin, "o mais apto ao meio sobrevive" (ALUN016J) 20

O texto de Dóris faz uma ligação com os textos de MENDONÇA, “Análise linguística no ensino médio: Um novo olhar, um novo projeto." e SUASSUNA, MELO e COELHO. "O projeto didático: forma de articulação entre leitura, literatura, produção de texto e análise linguística", pois ambos tratam da questão de como a literatura é estudada dentro da sala de aula. (ALUNO2L) ${ }^{21}$ (Grifos no original)

\footnotetext{
${ }^{19}$ Este texto resenha o artigo "Ensino situado em gramática: uma proposta para o ensino fundamental e médio", de Rosângela Rodrigues Borges e Elias Ribeiro da Silva.

${ }^{20}$ Este texto resenha o artigo "Análise crítica do discurso de pronunciamentos da polícia militar durante manifestações populares", de Micheline Mattedi Tomazi.

${ }^{21}$ Este texto resenha o artigo "A estilística da enunciação para o estudo da prosa literária no ensino médio", de Dóris Arruda C. da Cunha.
}

DOI: https://doi.org/10.32988/rep.v10n1.1561

Dossiê "Possibilidades de trabalho com a Língua Portuguesa"

\begin{tabular}{|l|l|l|l|l|l|l|}
\hline Revista (Entre Parênteses) & Alfenas, MG & v. 10 & n. 1 & $1-33$ & e021013 & 2021 \\
\hline
\end{tabular}




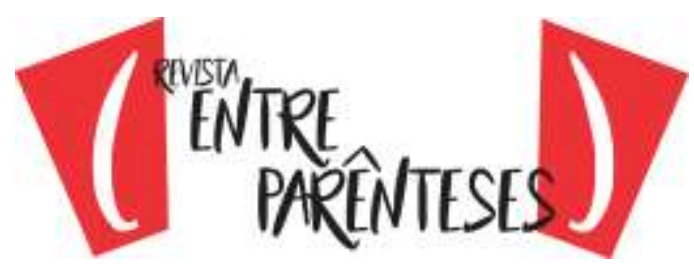

ISSN 2238-4502

No primeiro trecho, a intertextualidade ocorre com a utilização de uma ideia bem difundida durante o ensino médio, já que é nesse período que se estuda a teoria de Darwin. Já no segundo trecho, o aluno faz a ligação de uma ideia com a presente em outros textos que leu, provavelmente, já como aluno universitário, visto que ele faz questão de citar o nome do texto e o sobrenome dos autores. É interessante observar que esse trecho foi retirado de uma resenha em que, num outro momento, para citar o nome de determinado autor, o escrevente utiliza somente o primeiro nome, conforme já foi mostrado, e, quando a citação de outros autores é feita nessa parte do texto, já aparecem os sobrenomes desses pesquisadores. 0 escrevente está tentando se inserir como um indivíduo familiarizado com as práticas de escrita no ambiente acadêmico, mas ainda não internalizou, por completo, alguns aspectos.

Interessante ainda destacar o uso que esse escrevente (ALUNO2L) faz com o sobrenome dos pesquisadores citados. Ele utiliza esses sobrenomes em letras maiúsculas, como se estivesse referenciando os artigos citados. Ao mesmo tempo em que podemos perceber um distanciamento do contexto universitário, já que o aluno faz a citação do autor de modo inadequado, pode ser percebida uma tentativa de aproximação com o discurso da academia. 0 escrevente já percebeu que, em determinado momento, usa-se, para citar um autor, o seu sobrenome em maiúscula. Essa aproximação ficaria ainda mais nítida se o aluno tivesse acrescentado, entre parênteses, o ano da publicação.

Outra marca bastante interessante e que também evidencia uma tentativa de inserção dos escreventes nas práticas de escrita da academia refere-se à descrição do que é exposto no texto lido e à avaliação do texto lido que é expressa por meio de palavras qualificadoras. Os escreventes, por já terem ouvido falar que é necessário, na produção de uma resenha, comentar e expor os aspectos mais interessantes e, além disso, avaliar o texto lido, apresentam trechos que indicam esse comentário/valoração e também algumas palavras qualificadoras para indicar a avaliação. Tal fato evidencia, assim, uma atitude do escrevente em relação às ideias apresentadas pelo autor, indicando, por exemplo, a necessidade de alguma informação ser mais bem explicada.

Em uma das resenhas de uma obra cinematográfica, ${ }^{22}$ a fim de demonstrar uma avaliação positiva da obra, o escrevente diz:

O filme conquista o espectador pelo excelente roteiro. (ALUNO10A)

o final da história é chocante, ou melhor, é uma lição de vida. (ALUNO10A)

Mais à frente, para indicar que o texto relaciona-se à realidade, esse mesmo escrevente afirma:

22 Este texto resenha o filme "Bullying - provocações sem limites”, dirigido por Josetxo San Mate.

DOI: https://doi.org/10.32988/rep.v10n1.1561

Dossiê "Possibilidades de trabalho com a Língua Portuguesa"

\begin{tabular}{|l|l|l|l|l|l|l|} 
Revista (Entre Parênteses) & Alfenas, MG & v. 10 & n. 1 & $1-33$ & e021013 & 2021 \\
\hline
\end{tabular}




\section{(")}

ISSN 2238-4502

Acompanhamos nesse filme uma abordagem que condiz com a realidade. (ALUNO10A)

A história é tão verossímil e revoltante que nos da vontade de entrar no filme, denunciar a gangue e proteger Jordi. (ALUNO10A)

Nesse trecho, ao fazer uso de determinadas palavras, como "excelente", "chocante", "verossímil", por exemplo, o escrevente deixa bem evidente a avaliação da obra cinematográfica, indicando, possivelmente, que assistir a essa obra pode ser uma interessante escolha, visto que há, no filme, "uma abordagem que condiz com a realidade". Além disso, é bastante relevante destacar o vocabulário utilizado como uma tentativa de o escrevente se inserir como estudante do curso de Letras, uma vez que as escolhas lexicais podem encaminhar para uma caracterização específica desse produtor: a de alguém que conhece a área sobre a qual está discorrendo, ou seja, pode ser considerado um membro desse meio.

Um outro escrevente, em relação a um artigo que analisa peças publicitárias de uma determinada marca, ${ }^{23}$ comenta sobre o conteúdo do texto lido:

Todos esses recursos são apontados e explicados pela autora para que saibamos, na prática, como as peças publicitárias atuam na mídia para convencer o receptor a comprar seu produto. O exemplo das campanhas da marca Bom Bril foi uma escolha muito feliz, pois é uma marca bastante conhecida e caracterizada por possuir propagandas criativas. (ALUNO22D)

A avaliação do texto, nesse trecho, é indicada quando o escrevente utiliza os termos "uma escolha muito feliz", evidenciando que o objeto de pesquisa a que o texto se refere é bastante interessante e que pode, de certo modo, trazer alguma contribuir para os estudos da área.

Apesar de termos demonstrado até o momento, nas resenhas, exemplos isolados ora de marcas que remetem a produções da educação básica, ora de produções específicas do contexto universitário, essas ruínas aparecem, em muitos momentos, ao mesmo tempo, em uma mesma resenha. Vejamos, a seguir, uma resenha ${ }^{24}$ em que os aspectos discutidos se fazem presentes concomitantemente:

\footnotetext{
${ }^{23}$ Este texto resenha o artigo "Peças publicitárias 'Bom Bril': uma análise discursiva”, de Ângela Rezende Almeida e Rosângela Rodrigues Borges.

${ }^{24}$ Este texto resenha o artigo "A estilística da enunciação para o estudo da prosa literária no ensino médio", de Dóris Arruda C. da Cunha.

DOI: https://doi.org/10.32988/rep.v10n1.1561

Dossiê "Possibilidades de trabalho com a Língua Portuguesa"

\begin{tabular}{|l|c|c|c|c|c|c|}
\hline Revista (Entre Parênteses) & Alfenas, MG & v. 10 & n. 1 & $1-33$ & e021013 & 2021 \\
\hline
\end{tabular}




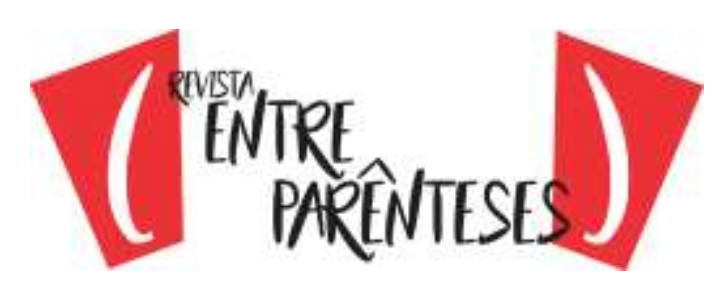

ISSN 2238-4502

Dóris trata no seu texto sobre o ensino de literatura no ensino médio a partir da estilística da enunciação, citando como embasamento teórico Bakthin. Então a partir dos estudos de Bakthin a autora aponta que esses podem ser utilizados para o ensino de literatura na sala de aula.

Para expressar à importância do ensino de literatura na sala de aula a autora usa do livro didático para apresentar a forma como a estilística e a enunciação são abordadas nos mesmos. Porém vale ressaltar que com a leitura de textos trabalhados anteriormente que a literatura é "deixada de lado" dentro da sala de aula, então ao se utilizar do livro didático (que também apresenta problemas dos mais diversos) para apresentar a estilística e a enunciação podem não dar muito êxito. Dóris apresenta que em alguns modelos de livros didáticos possuem fundos teóricos e outros possuem muitas incoerências sobre a noção de língua e exercícios teóricos.

O texto de Dóris faz uma ligação com os textos de MENDONÇA, "Análise linguística no ensino médio: Um novo olhar, um novo objeto." e SUASSUNA, MELO e COELHO. "O projeto didático: forma de articulação entre leitura, literatura, produção de texto e análise linguística" pois ambos tratam da questão de como a literatura é estudada dentro da sala de aula.

Em sua conclusão a autora aponta a necessidade da reformulação das aulas de literatura por meio da estilística e a enunciação. A questão da necessidade de melhorar o ensino de literatura na escola é muito discutida por diferentes autores, como visto acima e cada vez mais mudanças são necessárias para que o aluno não acabe saindo da escola sem esse conhecimento. (ALUNO2K)

A resenha apresentada contém elementos que tanto podem nos indicar ruínas de produções da educação básica, como a redação escolar e a redação do Enem, quanto de textos do contexto universitário. Logo no início da resenha, o escrevente utiliza, para referenciar o autor do texto resenhado, o primeiro nome, ou seja, "Dóris", no lugar do sobrenome do autor. Esse recurso é utilizado em mais de um momento do texto. No entanto, para o escrevente apresentar vozes de outros autores na resenha, o que pode nos indicar indícios de uma intertextualidade, utiliza o sobrenome dos autores "MENDONÇA" e "SUASSUNA, MELO e COELHO". Como comentamos, esse recurso é utilizado de modo diferente, isto é, por meio de letras maiúsculas, uma vez que parece se assemelhar um pouco mais ao que as regras da ABNT propõem.

Há ainda, na resenha, o uso de um vocabulário que pode nos remeter às práticas de escrita do contexto universitário, mais especificamente, de graduandos em Letras, numa tentativa de o escrevente se mostrar como um estudante desse curso. Os recursos utilizados para esse fim são, por exemplo, "estilística da enunciação", "embasamento teórico Bakthin" e "fundos teóricos". Em contrapartida, para concluir o texto, o escrevente apresenta, de forma menos evidente, uma proposta de intervenção "a autora aponta a necessidade da reformulação das aulas de literatura" e "cada vez mais mudanças são necessárias", estabelecendo uma relação com a redação do Enem.

Conforme tentamos demonstrar, a produção de determinado gênero discursivo pode estar submetida a uma relação com outros gêneros, de modo que, no momento em que o escrevente se propõe a redigir um gênero com o qual não tem familiaridade, pode se valer dos seus conhecimentos sobre outros gêneros. Tal fato pode ser percebido nas resenhas produzidas por alunos dos períodos iniciais de um Curso de Letras, em que os escreventes, como ainda não

DOI: https://doi.org/10.32988/rep.v10n1.1561

Dossiê "Possibilidades de trabalho com a Língua Portuguesa"

\begin{tabular}{|c|c|c|c|c|c|c|} 
Revista (Entre Parênteses) & Alfenas, MG & v. 10 & n. 1 & $1-33$ & e021013 & 2021 \\
\hline
\end{tabular}




\section{("E⿵trire}

ISSN 2238-4502

dominavam o gênero resenha, utilizaram de marcas de outros gêneros, como a redação escolar e a redação do Enem, para a produção desse novo texto. No entanto, ao mesmo tempo em que esses escreventes demonstram se valer de características da redação escolar e da redação do Enem para produzir uma resenha, apresentam algumas marcas que demonstram uma tentativa de inserção nas práticas de escrita do contexto universitário.

Dessa forma, por meio dessas marcas e também das características da redação escolar de que se valem, percebemos a presença de ruínas de um gênero em outro, assim como afirma Côrrea (2006), e vemos essas ruínas como algo positivo, ou seja, que faz parte da constituição do gênero novo que está em processo de produção. Assim, se a presença dessas interferências (não se emprega, aqui, esta palavra com um sentido negativo) é constitutiva desse gênero, não há como conceber que possa se ensinar verdadeiramente a produção de um gênero discursivo com base em modelos prontos e estanques, como, muitas vezes, pretende-se na educação básica, conforme tentamos demonstrar pela análise de alguns materiais direcionados ao ensino da dissertação. Com isso, é possível perceber também uma nova orientação/concepção de linguagem que dá muito mais valor às escolhas do escrevente do que ao fato de ser necessário que ele se adapte a determinado modelo. Concebe-se, assim, a linguagem como um acontecimento, em que o produtor, dentro dos limites de produção de um gênero do discurso, tem a opção de realizar escolhas para conseguir contemplar a produção de sentidos. Assim, entende-se que, ao adotar tal concepção de linguagem, nosso trabalho volta-se à consideração de uma multiplicidade de práticas tanto de escrita quanto de leitura que constituem o que denominamos como letramentos (STREET, 2007).

\section{Considerações finais}

Nosso objetivo foi analisar as ruínas do gênero redação escolar em resenhas produzidas por alunos dos períodos iniciais do Curso de Letras de uma universidade sulmineira a fim de elaborar conceitos de trabalho para o ensino de escrita, em especial, do gênero resenha. Dessa forma, percebemos que, para produzir um texto com o qual o estudante provavelmente não teve muito contato, ele se valeu da estrutura composicional de outros gêneros, como a redação escolar e a redação do Enem. Tal aspecto pôde ser evidenciado, por exemplo, por meio da estrutura do texto que, ora indicava uma relação com a redação escolar e com a redação do Enem, ora com a resenha. Assim, por meio da estrutura, evidenciou-se, de certo modo, um diálogo com as práticas de letramentos escolares típicas da educação básica na escrita do gênero discursivo resenha.

Além disso, a escolha lexical feita pelos alunos pôde indicar também, como vimos, uma relação com a resenha, na medida em que, em alguns momentos, demonstra uma avaliação do texto lido e, em outros, o posicionamento do estudante como um aluno do curso de graduação em Letras, bem como a apropriação de algumas regras que compõem a escrita nessa esfera discursiva. Ademais, os pontos de contato com a escrita acadêmica evidenciaram-se

DOI: https://doi.org/10.32988/rep.v10n1.1561

Dossiê "Possibilidades de trabalho com a Língua Portuguesa"

\begin{tabular}{|l|c|c|c|c|c|c|}
\hline Revista (Entre Parênteses) & Alfenas, MG & v. 10 & n. 1 & $1-33$ & e021013 & 2021 \\
\hline
\end{tabular}




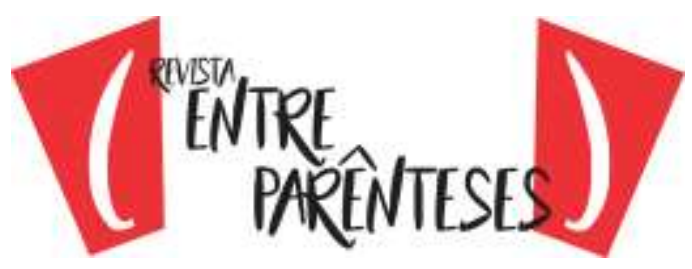

ISSN 2238-4502

também na utilização de outros teóricos/textos por parte do escrevente, indicando que o aluno, ao ler o texto que iria resenhar e mesmo durante a produção da resenha, estabeleceu um diálogo com outros autores com os quais provavelmente já havia tido algum contato. Todos esses aspectos mostram, portanto, a tentativa do escrevente de se inserir nas práticas de escrita do contexto universitário.

Assim, podemos perceber que, ao recorrer à determinada estrutura, as práticas de escrita próprias da educação básica orientaram a escrita de gêneros novos ou, pelo menos, daqueles com os quais o estudante não estava familiarizado. No entanto, como comentamos, não só existem ruínas do gênero redação escolar ou da redação do Enem na escrita desses alunos, uma vez que foram evidenciadas também algumas marcas da escrita da esfera universitária. Ao fazer uso de palavras específicas (sempre levando em consideração o seu objetivo com essa utilização) e apresentar pontos de contato com outros textos e temas, num processo dialógico, o estudante demonstrou que suas práticas de escrita produzidas estão em um trânsito entre a escrita da educação básica e a do ensino superior.

Entendemos que há ruínas de um gênero em outro e que essas ruínas podem nos demonstrar a tentativa do estudante de tentar se inserir em uma esfera de atividade humana (a universidade, no nosso caso) em que determinadas práticas de leitura e de escrita são exigidas. Defendemos ainda que o trabalho com a escrita, de um modo geral, precisa deixar de ser baseado na prática de ensino fundada na noção de linguagem como adequação ao modelo. Como já dissemos, se o professor opta por impor ou mesmo propor um modelo a ser seguido, pode ocorrer um certo apagamento do sujeito na medida em que o trabalho de se pensar na finalidade do texto, nos seus interlocutores, na situação comunicativa, no projeto enunciativo do escrevente, por exemplo, é posto em segundo plano. Dessa forma, o foco da proposta de ensino, contraditoriamente, volta-se para a obtenção de uma avaliação satisfatória por parte daquele que se constitui como único leitor do texto, o professor.

Defendendo que o trabalho com a escrita não deve ser focalizado de modo prioritário no modelo de texto, propomos como possíveis encaminhamentos para se pensar o ensino de escrita: (1) a leitura e a discussão de diferentes textos do mesmo gênero a fim de que se analise como se deu, por parte do escrevente, a construção de cada texto em particular; (2) a análise de cada texto, em seus mais diferentes aspectos, tais como: os recursos linguísticos utilizados na construção da coesão e coerência, da argumentação e da progressão temática do texto; a estruturação do texto em si, isto é, como o escrevente dispôs as informações, de que forma fez a paragrafação, que relação de sentido estabeleceu entre o título e o texto em si; as escolhas lexicais, indicando, por exemplo, alguns aspectos característicos do gênero, a posição do escrevente, bem como o domínio e a forma como o escrevente combina essas escolhas e por que as escolhe e (3) a leitura e discussão de textos de diferentes gêneros ou de um mesmo gênero produzido por diferentes escreventes a fim de compará-los, verificando aspectos produtivos usados nesses gêneros que poderiam ser pensados para a construção de outro.

Dessa forma, ao privilegiar o trabalho com as relações intergenéricas, o professor poderá analisar, pensando num ensino produtivo de língua(gem), como se dá o processo de

DOI: https://doi.org/10.32988/rep.v10n1.1561

Dossiê "Possibilidades de trabalho com a Língua Portuguesa"

\begin{tabular}{|l|l|l|l|l|l|l|} 
Revista (Entre Parênteses) & Alfenas, MG & v. 10 & n. 1 & $1-33$ & e021013 & 2021 \\
\hline
\end{tabular}


construção do texto, ou seja, quais foram as apostas do escrevente para produzir o texto proposto, e não somente olhar o texto como um produto a ser reproduzido, um produto dado e acabado. Entendemos, contudo, que, mesmo realizando um trabalho desse modo, não é possível apresentar, por exemplo, durante a análise do texto, todos os recursos efetivamente utilizados se considerarmos que a linguagem é sempre opaca e não transparente. No entanto, o fato de o professor, na construção de uma resenha, propor um diálogo com outros textos, já foge à ideia de adequação a um modelo. Evidencia-se, com isso, um trabalho que considera as experiências sociais dos alunos para a construção de novos e variados gêneros do discurso, vendo as ruínas de um gênero em outro como positivas, como algo que pode auxiliar não somente a construção da escrita de um texto em específico, mas das práticas de letramentos desse escrevente.

\section{REFERÊNCIAS}

AZEVEDO, Adélia Maria Evangelista. "Procedimentos adequados” geram textos criativos - no subgênero redação de vestibular UFMS/inverno 2002? In: BERTOLDO, Ernesto Sergio; MUSSALIM, Fernanda. Análise do discurso: aspectos da discursividade no ensino. Goiânia: Trilhas Urbanas, 2006. p. 209-235.

BAKHTIN, M. M. (1895-1975). Estética da criação verbal. Tradução a partir do francês por Maria Emsantina Galvão G. Pereira. 2. ed. São Paulo: Martins Fontes, 1997.

BRASIL. A redação no Enem 2013 - Guia do Participante. Disponível em: http://download.inep.gov.br/educacao_basica/enem/guia_participante/2013/guia_participa nte_redacao_enem_2013.pdf Acesso em: 03 jun. 2021.

BUIN, Edilaine; CONCEIÇÃO, Rute Izabel Simões. Entre a forma e a função: gênero painel e exercício da escrita acadêmica na graduação em Letras. (no prelo).

CÁLIS, Orasir Guilherme Teche. Quando as memórias são a matéria: memoriais de professoras alfabetizadoras e instabilidade genérica. 2015. 303f. Tese (Doutorado em Letras) - Universidade de São Paulo, São Paulo.

CAPRISTANO, C. C.; OLIVEIRA, E. C. Escrita infantil: a circulação da criança por representações sobre gêneros discursivos. Alfa: Revista de Linguística, 2014 (Aceito para publicação: a sair no volume 58, n.1,2014).

CORRÊA, Manoel Luiz Gonçalves. A visão dialógica do enunciado: linguagem, língua e dialogia. In: ___ Linguagem e comunicação social: linguística para comunicadores. São Paulo: Parábola, 2002. Cap. 6. p. 66-71.

. A visão saussuriana: linguagem, língua e fala. In: . Linguagem e comunicação social: linguística para comunicadores. São Paulo: Parábola, 2002. Cap. 2. p. 21-30.

. Heterogeneidade da escrita: a novidade da adequação e a experiência do acontecimento. Filologia e Língua Portuguesa. Brasil, v.8, p. 269-286, 2007.

DOI: https://doi.org/10.32988/rep.v10n1.1561

Dossiê "Possibilidades de trabalho com a Língua Portuguesa"

\begin{tabular}{|l|l|l|l|l|l|l} 
Revista (Entre Parênteses) & Alfenas, MG & v. 10 & n. 1 & $1-33$ & e021013 & 2021
\end{tabular}




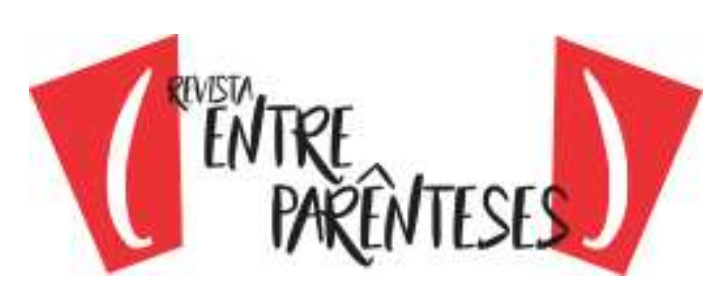

ISSN 2238-4502

Relações intergenéricas na análise indiciária de textos escritos. Trab. Linguística Aplicada. Campinas, 45(2): 205-224, Jul./Dez. 2006.

DA SILVA, Elizabeth Maria. Gêneros textuais em provas de vestibular: correlação entre jogos enunciativos e histórico de letramento. In: REINALDO, Maria Augusta; MARCUSCHI, Beth; DIONISIO, Angela. (Orgs.) Gêneros textuais: práticas de pesquisa e práticas de ensino. Recife: Ed. Universitária da UFPE, 2012. p. 135-156.

FIAD, Raquel Salek. A escrita na universidade. Revista da ABRALIN, Belém, v. Eletrônico, n. Especial, p. 357-369, 2- parte 2011. Disponível em:

<http://www.abralin.org/site/data/uploads/revistas/2011-vol-especial-2o-parte/raquelsalek-fiad.pdf> Acesso em: 16 maio. 2021.

GINZBURG, Carlo. Chaves do Mistério: Morelli, Freud e Sherlock Holmes. In: ECO, U.; SEBEOK, T. A. (Org.) 0 signo de três: Dupin, Holmes, Peirce. Tradução: Silvana Garcia. São Paulo: Perspectiva: 1991. p. 149-169.

MOTTA ROTH, Désiree; HENDGES, Graciela H. Apresentação. São Paulo: Parábola Editorial, 2010.

OLIVEIRA, Jorge Leite de. Resenha. In: Texto acadêmico: técnicas de redação e de pesquisa científica. 6. ed. ampliada e atualizada. Petrópolis: Vozes, 2009. Cap. 3. p. 113-119.

SILVA, Marcelo Clemente. Gêneros da escrita acadêmica: questões sobre ensino e aprendizagem. In: REINALDO, Maria Augusta; MARCUSCHI, Beth; DIONISIO, Angela. (orgs.) Gêneros textuais: práticas de pesquisa e práticas de ensino. Recife: Ed. Universitária da UFPE, 2012. p. 97-115.

STREET, Brian. Perspectivas interculturais sobre o letramento. Filologia e Linguística Portuguesa, São Paulo, v. Eletrônico, n. 8, p. 465-488, 2007. Disponível em: <http://www.revistas.usp.br/flp/article/view/59767/62876> Acesso em: 16 maio 2021.

TFOUNI, Leda Verdiani. A dispersão e a deriva na constituição da autoria e suas implicações para uma teoria do letramento. In: MARCUSCHI, Luiz Antônio et al; SIGNORINI, Inês (org.). Investigando a relação oral/escrito e as teorias do letramento. Campinas: Mercado de letras, 2001. Cap. 3, p. 77-94.

VOLOSHINOV, Valentin N.; BAKHTIN, Mikhail. M. Discurso na vida e discurso na arte (sobre poética sociológica). Tradução para uso didático da versão inglesa de 1976: Carlos Alberto Faraco e Cristóvão Tezza, s.d. (Texto originalmente publicado em russo, em 1926). Disponível em: <http://pt.scribd.com/doc/96529004/M-Bakhtin-Discurso-Na-Vida-Discurso-NaArte>. Acesso em: 04 maio 2021.

Recebido em 28/12/2020

Aceito em 07/01/2021

Publicado em 30/06/2021

DOI: https://doi.org/10.32988/rep.v10n1.1561

Dossiê "Possibilidades de trabalho com a Língua Portuguesa"

\begin{tabular}{|l|l|l|l|l|l|l} 
Revista (Entre Parênteses) & Alfenas, MG & v. 10 & n. 1 & $1-33$ & e021013 & 2021 \\
\hline
\end{tabular}




\title{
(")
}

ISSN 2238-4502

\section{THE PRODUCTIVITY OF RUINS OF THE WRITING THE ENEM IN REVIEWS AT THE UNIVERSITY}

\author{
Maria Luiza Alves \\ PG-Universidade Estadual de Campinas \\ (marialuiza.11@hotmail.com)
}

\begin{abstract}
This work aims to analyze ruins (CORRÊA, 2006) of the school writing genre present in the review genre. Specifically, it is intended, seeking to reflect on how the teaching of writing has been developed at these levels of schooling: (a) to analyze how the writer makes use of the compositional structure of other genres in the preparation of a review; (b) investigate to what extent the writer dialogues with school literacy practices typical of basic education and how these practices are used in the elaboration of the review genre; (c) analyze how the writer inserts (or tries to insert himself) in writing practices in the academic sphere and (d) reflect on the teaching of writing in basic education and at the university based on the evidence of the image that the writer makes of writing at these levels of schooling. The corpus are reviews produced by Literature students in two events: an extension course and a compulsory subject of the Literature Course at a public university. For the analysis, we opted for the evidential paradigm (GINZBURG, 1991) in order to identify linguistic clues for the analysis of the writer's gestures in the production of the review genre. Thus, it was verified, through the lexical choices and also the structure of the reviews produced, a transit in the writing of the writer between the writing of the entrance exam and the review, since now a dialogue was presented with the typical school literacy practices of the basic education, sometimes with the writing practices of the university context. This aspect reinforces the idea that working with writing, in general, should distance itself from the notion of language as an adaptation to the model to give way to the conception of writing as a process and language as an event. It is concluded that the ruins of one genre in another can be a positive resource for the construction of the writing practice of the review genre and, consequently, of this writer's literacy practices.
\end{abstract}

Keywords: Literacy. Academic writing. School writing.

DOI: https://doi.org/10.32988/rep.v10n1.1561

Dossiê "Possibilidades de trabalho com a Língua Portuguesa"

\begin{tabular}{|l|l|l|l|l|l|l} 
Revista (Entre Parênteses) & Alfenas, MG & v. 10 & n. 1 & $1-33$ & e021013 & 2021 \\
\hline
\end{tabular}




\title{
(")
}

ISSN 2238-4502

\section{LA PRODUCTIVIDAD DE LAS RUINAS DEL DISERTACIÓN/ESCRITURA DE ENEM EN RESEÑAS EM LA A UNIVERSIDADE}

\author{
Maria Luiza Alves \\ PG-Universidade Estadual de Campinas \\ (marialuiza.11@hotmail.com)
}

\begin{abstract}
Resumen
Este trabajo tiene como objetivo analizar las ruinas (CORRÊA, 2006) del género redacción escolar presentes en el género reseña. En concreto, se pretende reflexionar sobre cómo se ha desarrollado la enseñanza de escritura en estos niveles educativos: (a) analizar de qué manera el escribiente hace uso de la estructura formativa de otros géneros en la preparación de una reseña; (b) investigar el grado en que el escribiente hace diálogos con prácticas de literacidades escolares típicas de la educación básica y de qué forma se utiliza de estas prácticas en el desarrollo del género reseña; (c) examinar cómo el escribiente intenta adentrarse en las prácticas de escritura de la esfera académica y (d) reflexionar sobre la enseñanza de la escritura en la educación básica y en la universidad a partir de las amuestras que el escribiente hace de la escritura en estos niveles de escolaridad. Por lo tanto, se utilizaron, como el corpus de este trabajo, reseñas producidas por un grupo de estudiantes, recogidas en dos eventos separados, en un Curso de Extensión Universitaria y en una asignatura obligatoria para los estudiantes de Carrera de Letras de una universidad sul-mineira. Para el análisis, se optó por el paradigma indiciário (GINZBURG, 1991) con el fin de identificar las claves lingüísticas para el análisis de los gestos del escribiente en la producción del género reseña. Se verificó, a través de las opciones léxicas y la estructura de las reseña producidas, un tránsito en la escritura del escribiente entre la redacción de exámenes para la universidad y la reseña, ya que ahora apareció un diálogo con prácticas de literacidad escolares típicas de educación básica, ahora con las prácticas de escritura del contexto universitario. Este refuerza la idea de que el trabajo con la escritura, en general, debe distanciarse de la noción del lenguaje como adecuación al modelo para dar paso a la concepción de la escritura como un proceso y el lenguaje como un evento. Llegamos a la conclusión de que las ruinas de un género en otro pueden establecer un recurso positivo para la construcción de la práctica de la escritura del género reseña y, por lo tanto, de las prácticas de literacidades de este escribiente.
\end{abstract}

Palabras clave: Literacidades. Escritura académica. Redacción escolar.

DOI: https://doi.org/10.32988/rep.v10n1.1561

Dossiê "Possibilidades de trabalho com a Língua Portuguesa"

\begin{tabular}{|l|c|c|c|c|c|c|} 
Revista (Entre Parênteses) & Alfenas, MG & v. 10 & n. 1 & $1-33$ & e021013 & 2021 \\
\hline
\end{tabular}

